\title{
"Making us see science" Visual images in popular science articles and science journalism
}

\section{BY HARALD HORNMOEN}

The article explores how scientific research and scientists are represented visually in popular science and science journalism. It discusses communicative functions and cultural meanings of visual elements in science stories. Drawing on concepts from the visual grammar developed by Gunther Kress and Theo van Leeuwen, the author indicates how different kinds of modality are used to address the audience in popular science articles in Scientific American and Illustrert Vitenskap (a Scandinavian magazine). It is argued that the visual elements in popular scientific magazines are conventionally arranged in a manner coinciding with a pedagogical/educational intent typical of much popular science, taking the readers from a reality they are presumed to have experienced towards more abstract scientific knowledge. However, the two magazines analyzed differ markedly with respect to the audience competence that they implicate in their visual representations. The level of visual abstraction in Scientific American contributes to creating an identity for its audience as belonging to well-educated and advanced elites, as opposed to the images of Illustrert Vitenskap, where the emphasis is to a larger extent on a naturalistic coding. The author goes on to discuss how photographs, visual composition and verbal text work together in a multimodal rhetoric typical of many science and health stories in Norwegian newspapers. 


\section{Introduction}

Illustrations representing spectacular explosions in the universe; diagrams attempting to show how nerve cells communicate; photographs depicting scientists in lab coats staring at test tubes: Such visual images occur quite frequently in popular science stories.

Mediated visual images do not simply accompany verbal texts. They actively organize meaning and invite to be interpreted in particular ways (Kress \& van Leeuwen 1990, 1996, Veel 1998). However, little research has been done on how images create meaning in popular science and science journalism. This is a bit surprising considering the salient use of visual elements (such as graphical illustrations, photographs, drawings) not only in television programmes and popular science magazines like Scientific American and New Scientist, but also as a part of the specialized science pages or the science-related material in the news sections of daily newspapers.

This article explores how scientific research and scientists are represented visually in popular science and science journalism, and it discusses communicative functions and cultural meanings of visual elements conventionally used in science stories. I limit my analysis to samples from newspapers and popular science magazines. The journalistic articles mainly focus on research topics within medicine or the natural sciences.

I use both the term "popular science" and "science journalism" in order to encompass visual images represented in a popular science magazine like Scientific American (where most of the articles are written by scientists, not professional journalists) as well as images in articles about scientific research in newspapers. The latter are written by so-called independent journalists in my samples. However, the term "science journalism" is not limited to include only articles displaying a critical attitude or approach to their subject. Rather, I find it difficult to point out distinct visual features in journalistic articles that have a different approach to their subject than primarily attempting to popularize or explain developments in scientific research for an audience of non-professionals in the field reported on. 
When I devote a relatively large part of the text to analyzing Scientific American (SA), it is because of the influence that the more than 150-year-old magazine has had on the formation of popular science, including its visual dimension. The Scandinavian magazine Illustrert Vitenskap (IV) has been somewhat influenced by SA visually. But IV has a markedly more populist orientation than SA, thus allowing for a fruitful comparative analysis of how visual images are presented to different readerships of popular science. I have also chosen to analyze images appearing in large newspapers in Norway (such as Aftenposten and Verdens Gang), an objective here being to shed light on how such media visually attempt to attract reader attention to stories about science among other kinds of news stories found in newspapers.

Many readers may link an expression like "visual images in the media" to photographs. However, theoretical and methodological introductions to reading images normally analyze several dimensions of visual presentation such as graphic illustrations, the composition of visual elements in layout, the level of abstraction in illustrations and how images and words work together rhetorically. I will also touch on such dimensions by using some of the insights and concepts provided by Gunther Kress and Theo van Leeuwen $(1990,1996)$ in their account of the grammar of visual design.

Questions for the study are: How are visual images applied in popular science magazine articles and newspaper articles presenting scientific issues and findings? What are possible meanings and functions of the images and their composition in such articles?

In the first part of the article, I particularly examine how visual modalities are used in information graphics (visual representations of information or knowledge) commonly found in popular science magazines. In the second part, I analyze visual representations of science in Norwegian newspapers. Here I do not only look at information graphics applied in science news, but also at formulaic photographic depictions of scientists and how such photographs work together with verbal text in a multimodal rhetoric found in science and health stories. 
The analytical concepts discussed and applied in this study may hopefully contribute to what Norman Fairclough (1995: 201) calls "critical media literacy", that is a critical awareness of media discourse in social processes. More specifically, it is hoped that media students and practitioners may be made aware of how visual images not only mediate science and facilitate our understanding of research-generated knowledge, but also reflect power relations between participants such as scientific researchers and audiences/readerships. Such awareness may again stimulate reflection on how science could be visualized differently in the media.

Visual communication is becoming more and more crucial in the domains of public communication, and it may be - as Kress and Van Leeuwen predict - that: “'Visual literacy' will begin to be a matter of survival, especially in the workplace” (1996: 3).

\section{A narrative of nature?}

One of few substantial contributions to understanding the use of images in popular science is provided by discourse analyst Greg Myers (1990). He analyzes the ways in which the narratives are constructed in some articles in scientific journals (Science, Evolution, Hormones and Behaviour) and in articles by the same authors on the same topics for more popular journals, Scientific American and New Scientist. According to Myers, the texts in the scientific journals create a narrative of science, whereas the popularizing articles present a narrative of nature. What is meant by these concepts? Basically, that the "scientific" texts emphasize and are organized according to processes and concepts of scientific research, and this is reflected in the syntax, vocabulary and illustrations. The focus of the popularizing articles, on the other hand, is on the object of research rather than the research activity. In journalistic representations of natural science, the narrative is chronological and organized around nature (plants or animals may be the subject). The syntax, vocabulary and illustrations emphasize the externality of nature to scientific practices. 
Myers claims that the differences in the narratives of articles for professionals and those for popular audiences are even more apparent in the illustrations than in the verbal texts.

In one of the examples that Myers gives to support his assertion, he compares the visual representations in scientific journals with the use of images in a popularized account of the research in an article in SA. The articles are about biologist David Crew's research on the evolution of sexual behaviour and the systems that control reproduction in lizards and snakes. Crew's articles in scientific journals often have graphs showing cycles of various hormones. According to Greg Myers, the illustrations in the SA article, on the other hand, attract the readers' attention to the snakes themselves (to nature, in other words), rather than to the research as such. A painting of the snakes is reproduced on the cover of the magazine, and the introductory page of the article is dominated by a colour photograph of male snakes mating. The next pages feature a series of drawings of the mating behaviour of these garter snakes.

The four drawings of the snakes outline the stages in their mating behaviour and thus provide a narrative of nature for the article (Fig. 1). See the appendix for the figures referred to.

The article also features graphs of hormonal cycles, illustrating central findings of Crew's studies (Fig. 2). The way Myers sees it, SA at each stage includes a little picture showing sperm in the testicles or displaying little snakes growing in the eggs and then hatching. These are illustrations attempting to visualize for the non-specialist reader what the stages mean. And Myers claims that these illustrations "help the reader to focus attention on the organism rather than on the concept of cycles, or on the measurement of hormonal levels and the gonadal sizes that are the data reported here" (Myers 1990: 161). The same effect is not brought about by the "more stylized" sorts of graphs used in scientific journals such as the one in Hormones and Behavior (Fig. 3).

Myers' suggestion of a radical difference in the way the graphs in the texts of the professional and popular articles function is not particularly convincing. By visual means, SA communicates 
the concept of hormonal cycles rather than drawing attention to the organisms as such. But the graph in this magazine illustrates this in a pedagogical manner by also including illustrations of the organisms, in this case the snakes. The fact that the popular scientific magazine includes such representations does not necessarily imply that attention is drawn away from the scientific concepts, but rather that they aid our understanding of them by also showing explicitly the natural objects.

\section{Naturalistic and scientific modality}

In order to acquire a better understanding of the way images communicate meaning in different kinds of popular science articles, I find it useful to apply some of the concepts that Kress and van Leeuwen (1996) provide in their account of the grammar of visual design. This goes particularly for their concept of modality. The term 'modality' is from linguistics and refers to the truth value or credibility of statements about the world. In different social groupings there is a tendency that different expressions and criteria develop in order to decide what is more or less credible, true or real.

Kress and van Leeuwen accentuate some main modalities in our culture, or more precisely some 'coding orientations', which are sets of abstract principles that inform the way in which verbal texts and images are coded by specific social groups or within specific social contexts. Two of the main categories can be termed, with discourse analyst Per Ledin's formulations (Ledin 2000), 'naturalistic' and 'scientific' modality. In naturalistic modality, the visual representation of the world is based on norms stating that we observe the true world with the naked eye, whereas visual representation in scientific modality is based on norms according to which the truth is abstract: It is not accessible by close and spontaneous experience of reality and must be established by scientific principles. Briefly, the two kinds of modality can be expressed in the following way:

A naturalistic modality: A visualization coding the world according to our everyday sensory experiences, as we per- 
ceive it with the naked eye. The modality is marked by elements such as depth, detail, background and light being included in the representation.

A scientific modality: A visualization that does not stop at our everyday perception of the world, but probes beyond the visual appearance of things towards what is found 'below the surface', towards the general and principal. The modality is characterized by a suppression of elements such as depth, detail, background, light and shadow.

(The descriptions are from Ledin 1997: 49, my translation)

Different modalities address the audience in different ways. On the one hand, we can talk about visual elements relating to "what we see". Colour photographs often code reality in a way that relates to the viewers' everyday sensory experiences, at least we have a tendency to understand them in such a way. On the other hand, visual elements that relate to "what we know" present this knowledge at a greater distance from our everyday experiences. For example, graphs are conventionally regarded as expressing a more abstract or scientific modality. They are a kind of visual representation that omits background, depth and other dimensions conventionally contributing to an everyday spontaneous coding of reality.

Such categories of modality are not absolute, they are found in mixed forms. However, different social groups and institutions will accentuate different modalities depending on the context of communication. For instance, elite groups in society are more prone to use abstract visual modalities. One should not forget how the ability to produce or read signs grounded in this coding is a mark of social distinction, of being an 'educated person'.

\section{Modality and composition in magazines}

Popular science magazines typically apply mixed forms of modality in their visual presentations. This is characteristic of an elite-oriented magazine such as Scientific American as well as 
the Scandinavian magazine Illustrert Vitenskap ("Illustrated Science"), which markets itself as "The Nordic countries' largest magazine on nature, science and technology". In popular science magazines where the intention to a large extent is to convey "new" scientific findings or insights and at the same time create some understanding of scientific concepts and ways of reasoning (however different their ambitions in this respect), it is characteristic that the articles are presented as a mixture of verbal text and graphs and images - whether they are photographs or more or less naturalistic illustrations by drawings or paintings.

\section{Scientific American}

Let's have a look at SA first. Glancing through any recent edition, one is struck by the visual presentations of the magazine. Undoubtedly, they are eye-catching, even flashy when compared to the sparse line drawings of specialist journals - that is, if these journals include any illustrations at all.

But it is also a distinguishing trait of the articles in SA that the visual expressions mix different modalities. Very often, the visual layout of an article combines representations of "what we see" and of "what we know". As in the visualization of how the earth's carbon cycle can influence global climate and the role a plantlike organism plays in this process (Fig. 4).

The images of nature with mountains, the ocean, clouds, the sky, a volcano and the factory pipe represent 'what we see', whereas the arrows in the landscape that connect different elements in the picture accompanied by words and figures represent 'what we know', or at least what science has contributed to our knowledge about transport and causal connections in this cycle.

When different visual elements are organised in articles that cover several pages, they tend to follow a pattern where a naturalistic orientation precedes a scientific orientation. Characteristically, a naturalistic modality dominates the visual expression on the opening pages of the articles (together with the head and the lead), whereas more of a scientific or an abstract modality occurs further on in the article. This is illustrated by an 
article about a parasite bacterium with the ability to change the sex of or eliminate its hosts.

The story's layout begins with images (Fig. 5) of what we can see and relate to, at first a butterfly threatened by the parasite (the butterfly being beautiful and eye-catching - together with the visually salient word "sex" in the headline). Photographs of other insects influenced by the bacterium follow (Fig. 6), before the last composition of images covering two pages presents a more abstract graphic visualization of the parasite's adaptive tactics (Fig. 7).

Visually, there is in other words a movement from what is known, that is from images familiar to the reader, to more abstract representations - to what appears to be new information to the uninitiated in the field of research. In several of the larger graphic illustrations in SA, the visual elements are also distributed along a horizontal axis in such a way that those placed on the left are presented as given and the ones on the right as new. This is in accordance with a rule in Kress and van Leeuwen's grammar of visual design. This rule can be understood as one of the codes of spatial composition of visual elements, at least in western cultures. In the upper part of the illustration of how a particular kind of cells orchestrates the immune response against invaders (Fig. 8), the given (the human body) is typically placed to the left. The level of visual abstraction increases further to the right along a horizontal axis.

To a large extent, the images in a magazine like SA are arranged - together with the text - in a way that attempts to take the reader from a world she has experienced and is familiar with to a reality of more abstract scientific knowledge. This kind of movement is similar to what Robert Veel (1998) has observed as an effect of visual images in environmentalist texts for students.

The manner of switching between naturalistic and abstract visual modalities seems to have a kind of verbal parallel in what I have elsewhere characterized as a 'semi-narrative' form displayed in a lot of science journalism (this also applies to SA, see Hornmoen, Meyer \& Sylwan 2006). A typical way of structuring these texts is to have narrative parts (preferably in the opening and at the end of an article) alternate with parts devoted to ex- 
position. Whether they focus on the actions or the behaviour of human beings or other organisms, a main objective of the narrative parts is to create reader identification, whereas the expository parts describe, elucidate and discuss processes and findings of the research presented in greater detail.

But although many of the visual compositions undeniably have a pedagogical function, I emphasize that one finds exceptions to the rule of the given placed to the left and the new to the right in the double-paged compositions of this magazine. Graphs with a marked abstract modality often appear in the left part of the compositions. And it is certainly not always the case that graphic illustrations and diagrams explicitly offer the reader something she has "already seen" as a point of entrance to visual abstractions of the research presented. For instance, the illustration of a vaccine strategy against AIDS (Fig. 9) is at a considerable semiotic distance from what we see with 'the naked eye', in spite of some outlines of an arm and a syringe.

Illustrations such as this one signal the kind of audience the magazine addresses. To a larger extent than many other popular science magazines, the compositions of SA do take the readers' interest and competence in abstract visual codes for granted. The abstractions in the magazine's graphic illustrations also have a verbal parallel in a relatively frequent use of a specialized vocabulary in the articles. The specialized words and the abstract visualizations mark a 'differentness' in relation to both the everyday language and the more naturalistic images used. This 'differentness' does not only signal that the version of reality which this language presents (or creates) is 'alien' compared to the version presented by everyday language and naturalistic images. When such different signs are included to the extent that they are in SA, they also contribute to creating an identity for its readers as belonging to a well-educated and advanced socio-cultural elite.

\section{Comparing Scientific American with Illustrert Vitenskap}

In a rather clear contrast to SA, the visual compositions in IV signal that this magazine addresses a broader audience than elite groups in society. Although a curiosity about science to some extent is expected from the reader, the magazine hardly 
presupposes a special competence in abstract visual codes. That is not to say that the influence of a magazine like SA cannot be traced in this magazine's layout of text, images and graphs.

However, a naturalistic orientation is more dominant in IV. Differences between the two magazines stand out in their cover illustrations. Whereas SA seldom has naturalistic representations of human beings on its covers, such images as well as other motifs with a naturalistic modality commonly appear on the cover of IV. The covers of the two magazines issued in September 2003 (Fig. 10), both of them with neuroscience as their main story, hint at the influence of SA on IV. But the covers also indicate disparities in their visual aesthetics and ways of addressing the public. In IV, the human face is salient beneath the image of the brain. The glare of the eye can be interpreted as underscoring the mysteries in the headline ('hjernens mysterier' can be translated into 'the mysteries of the brain'). But the direct way of addressing the viewer also signals that this is a topic that concerns 'you', in other words the onlooker (or potential reader of the magazine).

The cover of SA to a larger extent appears as something to observe. When the human figure's head is depicted in profile, the viewer is positioned at a greater distance from it than from the motif of IV. The composition as a whole also requires more of an active interpretative role from the viewer in order for it to make sense at some level.

Moreover, the layout in IV more consistently follows a pattern where the naturalistic is positioned to the left, and illustrations with a somewhat more abstract coding are placed to the right. In a story about stress (Fig. 11), there is a visual appeal to the reader's recognition on the left of the two-page layout, while on the right there is a graph illustrating one's ability to perform and one's level of stress as well as the "new" information that research has generated. The graphic illustrations are less complex in this magazine, with a visualization that rarely invites the reader to reflect on the research being presented. A case in point is the layout for a story about an allegedly increasing IQ in the population (Fig. 12), the images here accompanying the headline's assertion "We are getting wiser and wiser". It is a kind of 
visual aesthetic that to a larger degree than SA's illustrations contributes to creating an image of scientific research as an activity about discovering more or less certain connections, or 'facts', in the world.

\section{Illustrations in the Norwegian press}

I now take a closer look at the visual dimension in journalism about science and research issues in the Norwegian press.

The press in Norway does not have an extensive specialized coverage of science and scientifically related issues (Eide \& Ottosen 1994, Hornmoen 1999). Apart from some specialized radio and TV programmes and a few specialized pages in the newspapers, science and research issues typically appear as a part of the general news coverage or as a part of other areas, for instance the coverage of health issues. I emphasize that the press uses scientists as so-called expert sources commenting on news events just as much as it lets them speak about scientific research as such. The activity of representing comments by experts hardly qualifies as 'science journalism'. But it is worth mentioning that when photographs of commenting experts are included in the story's layout, it is not unusual to arrange a setting that visually underscores their status as scientific experts, whether this is achieved by the photo capturing them in front of shelves upon shelves with books or in technologically authoritative laboratory settings (Fig. 13). Such illustrations serve to strengthen the credibility of the portrayed expert's message as well as strengthening the impression of the journalistic story as being a truthful representation of reality.

But quite often, one also sees visual compositions that are inspired by the popular science genre as it appears in magazines. The ambition is then, apparently, to convey scientific research findings or to situate news events within a research-based frame of understanding. For newspapers with sufficient financial resources, photographs or other kinds of illustrations with a marked naturalistic orientation are supplemented by more or less sophisticated graphs. Accompanying an article in the newspaper Aftenposten about Mars being closer to the earth than it has 
been for a long time, we can see the typical mix of modalities (Fig. 14). Here there is an illustration of the Neanderthals to the left and a more abstract modality to the right. However, the abstraction is not at the level characteristic of the graphs of Scientific American - the audience of the newspaper clearly being considered to be broader than that of SA.

Tendencies in the visualization of science issues in the press can be considered in relation to how these issues are represented and framed in words. In my own study of the science coverage in Norwegian daily newspapers (Hornmoen 2003), I identify some traits typical of how scientific research is represented in journalistic texts. Use of language and frames emphasizing the uniqueness and the awesome qualities of the phenomenon or issue exposed is widespread, whether this is a technological innovation as a result of research or the research activity itself or what is "uncovered" or "revealed" by this activity. Related to this is a preoccupation with findings or discoveries. In addition, many articles focus on the potential utility and the kind of application that can result from research.

Reports on so-called 'sensational' or 'unique' scientific discoveries have a long tradition in journalistic coverage of science. American journalists have called this "gee-whiz-reporting" or "breathless discovery stories" (see Blum and Knudson 1997). The visual correlate to this journalism is spectacular illustrations of what scientific research has 'revealed' or science-based technology has generated, so that the illustrations indirectly constitute a tribute to science or to the technology that has enabled them (Fig. 15, Fig. 16). Impressive motifs of celestial bodies, planets and stars repeatedly occur in articles about astronomy. However, the possibility of creating flashy images such as the SA illustration of explosions in the universe (Fig. 17) is more limited in newspapers than in magazines.

\section{Displaying the value of science}

Such spectacular illustrations are visual expressions of what rhetorician Jeanne Fahnestock (1993) has termed the wonder appeals characteristic of science journalism. Her viewpoint is that journalists try to reach and engage readers by being clear 
in their claims about the value of the scientific discoveries they report on. One way of doing that is praising or 'celebrating' the findings. In my view, spectacular illustrations of the kind mentioned invite the reader, or rather the viewer, to strike a position where she looks up to the phenomenon or object represented in humble admiration of what scientific research is capable of uncovering and technology can manage to produce.

More prosaic are the articles in health journalism presenting research with possible consequences for our health. But the illustrations of such stories also try to be explicit about the value of the research reported on. For an audience of non-experts, a recognized value in this area is how the research leads to further benefits, how it can be used to improve people's health. This kind of value requires the efforts of photographers and illustrators to make it visible in a newspaper layout. For instance, the visual composition in an article (Fig. 18) tries to establish a connection between the photograph and the graphic illustration right beneath it, so that the science-based vaccine method described appears to be relevant and important to the audience. In the photo, the researcher depicted (the researcher in a white lab coat, one notes) is looking at the mouse and the syringe, his glance in this way forming a so-called vector - in other words an imagined line, here emanating from the researcher's eyes. The direction of his glance leads the reader's glance towards the new vaccine which is the topic of the article (the article's headline may be translated into "New Norwegian vaccine method: can help against HIV and cancer"). For the reader, an image of a needle pricked into a laboratory mouse is hardly a striking expression of the vaccine's potential applicatory value. But in the total visual composition, the syringe also forms a vector down towards the graphic illustration's motif of a human arm which the needle is put into, this under the subtitle "This is how the new vaccine method works".

The more abstract modality that dominates the graphic illustration may presumably function - together with several specialized words in text beneath it - to convince the reader about the utility of the vaccine method. Words that are used here may give the reader the impression that 'the authoritative voice of sci- 
ence' is speaking. The irony is that the article's main text discloses that this vaccine method has still not been tested on human beings. In their eagerness to visualize the utility of the method, the illustrators end up promising more about its potential for application than what is reasonable based on the vaccine experiments. However, this kind of visualization is barely unfortunate for research groups seeking publicity and access to research funding through the media.

\section{Selling science through images}

Selling science though the media has become a main objective for many public relations professionals as well as researchers in scientific institutions (Nelkin 1995). Quite a lot of the science stories in the Norwegian press also suggest that journalists, photographers and layout professionals readily promote different types of research and try to create a public appreciation of scientists' need for more funding. Sometimes the mission on behalf of science can take on a form of argumentation strikingly similar to the rhetoric of advertising. A main goal of advertising is to set the recipients of a message in a mood that makes them receptive to the argumentation of the 'sender' of the message. A typical strategy is to oppose negative attitudes that one assumes the audience might have and open up to the positive sides of the product or the service. ("You may have been told that Fiat corrodes fast. You can forget that. We have now developed ...”).

A similar strategy can be traced in the Aftenposten story about Norwegian biotechnology "lagging behind" (Fig. 19). Particularly interesting here is how the photographs, the visual composition and the text work together in order to convince the reader about the necessity of investing more money in Norwegian biotechnology. A picture of a mouse with human ears - an image likely to arouse feelings of disgust - is positioned on the top left hand side of the page beside a large photograph of a bioengineer seeing "the future" and "the possibilities" of the industry. In the text beneath the photo of the mouse, the research leader in a biotech company is cited as saying that he understands that people regard images like the 'mouse with the human ear' as grotesque, but he also points out that he does not 
reckon that 'cultivation of ears' will become a major research trend in biotechnology. The lead and other parts of the text follow up by presenting common objections that people have and then let the leader argue against these or assert that "biotechnology is essentially not controversial". In this way, he is allowed to make way for the message: Norway is unfortunately lagging behind in this field, but it can become a great growth industry if these companies are given "the same possibilities to develop as in other European countries". At the bottom of the page, there is another picture that in contrast to the image of the mouse indirectly argues ethically in favour of this field of research. The illustration text tells the reader that what we see is "nice technology", a so-called "technomouse" that the participants in the picture are "caressing", a machine that, according to the text, will "spare the lives of 3,00o laboratory mice every year".

If the illustrations together with the text in this story attempt to put a so-called media-created image (the mouse with the ear signifying the scary biotechnology) to death, I am personally more struck by how the large picture contributes to maintain a cultural stereotype. The picture of the researcher glancing at the test tube and its content has become a visual cliché in newspapers. The image is especially used to illustrate stories about assumed developments within genetic research and biotechnology. This image is in many ways a continuation and transformation of a traditional cultural stereotype, namely the fortune teller with the crystal ball. The difference is that it is the researcher who is granted the ability to see the possibilities, to foresee the future.

Apart from creating cultural prejudices such as "scientific research is something that goes on in laboratories and is carried out by people with test tubes and white coats", I notice how this and other pictures with a similar motif (Fig. 20, Fig. 21), tend to construct a certain viewer position by the use of angles in the photograph. As Ledin (1997) notes, when the angle makes the viewer 'look up' towards the depicted, this gives the participants in the picture a symbolic power over the onlooker. Furthermore, he notes how images with participants depicted in profile situate the viewer at a distance where she is not expected to engage directly with them, unlike a depiction 'from the front' - face to face. 
In my three examples of 'researchers with tubes', two of them are depicted in profile, whereas the angle in all the photos are from below and up towards the researcher (although in varying degrees). The scientists are looking upwards at the test tubes (or the glass), so that the viewer's eyes are led to fixate what can be considered both an instrument in (the tubes) and a product of research (the content of the tubes) as if to signal: herein lie the possibilities, or herein is the solution, whether it is the solution to a lack of industrial innovation in Norway or, in a broader sense, the solution to the problems of mankind or the world's crises. These are images that create a distance in relation to their audience. To me, the images also transmit something beyond their overt message (the message that in this field of research there are vast possibilities). At another level, the pictures tell me that these possibilities are something that is reserved for these scientist experts, something they deal with. Even though their predictions and results to some extent will concern me, they are not something that I am an implicated participant in, something that I - or "the readers" in a wider sense - can join in and contribute to creating conditions for. The images create a distance to their audience in the same way as standardized science news formulations such as "scientists have shown" and the frequent references to "unique" scientific discoveries. The many images of researchers in white coats in science journalism work in the same way as the visualizations of 'spectacular' or 'awesome' objects of scientific research do. Above all, they invite the audience to look up to scientists and science in deep admiration and respect.

\section{Concluding remarks}

Let me sum up tendencies in how visual images are used in popular science and science journalism. A characteristic trait in popular science magazines is that they alternate between graphs, photographs, other types of illustrations and verbal texts. The illustrations of the stories often switch between a naturalistic modality and a more abstract modality in a way that can take the reader from a reality she is familiar with towards a reality con- 
sisting of more abstract scientific knowledge. However, there can be marked differences in the way a magazine like Scientific American and one like Illustrert Vitenskap addresses its readers. Graphic illustrations are less complex in IV than in SA. They hardly invite the reader to reflect on the represented research, which typically appears as an activity that discovers 'facts of the world'. In contrast, the more complex graphics in SA to a larger extent draw attention to the processes and concepts of science. Differences in the levels of visual abstraction indicate the two magazines' differing views of their readerships. In contrast to IV, SA creates an elite identity for its readers.

In major Norwegian newspapers, one also finds several examples of a visual mixture of naturalistic and abstract modalities. Moreover, visual motifs and compositions may be marked by how the articles highlight so-called "unique" research findings or emphasize the utility of the research. Whether they include spectacular illustrations of what new research has 'revealed' or pictures of researchers in white coats lifting test tubes, such popular science clichés invite their audience to look up to scientists and their activities in admiration. Often, the visual compositions are designed in a way that makes them suited to convince readers of the vast possibilities of the research reported on. This suggests that selling science and technology through journalistic coverage has become an objective not only for some researchers, but also for some journalists.

I have indicated some of the causes for such trends. They are partly the result of what editorial staffs consider as necessary communication strategies in order to make complex issues engaging. The images and layouts visually argue for the value of the research, in this way also reflecting how science stories in newspapers compete for reader attention with stories that have more obvious news value, such as crime stories. Furthermore, working within their media frames (time frames, for instance), the people who are responsible for the illustrations and the layout have to draw on a reservoir of formulaic expressions, or socalled schemata. A schema may be understood as a kind of model for the representation of different areas of reality (Kjørup 1995). The laboratory man in the white coat with a test tube is 
such a model of the scientist and science, a handy image to use in order to create recognition. This image is also invested with a cultural authority, something that, from the reader's viewpoint, may strengthen the status of journalism as a truthful account of reality.

Are there not other ways of representing science and sciencerelated issues visually in journalism? Certainly there are other ways, but I find it difficult to spot clear trends among them, for example as to what characterizes images accompanying articles representative of more critical science coverage. This may be partly due to such journalism seeing scientific research in a broader societal context and not necessarily focusing on research and developments within science as such. The use of images, then, does not necessarily become distinct or different compared to what one finds in critical journalism in other areas.

Let me end this article by relating the subject to my own practical experience as an editor and journalist of the magazine Apollon. This is a popular science magazine published by the University of Oslo. An editor of such a publication has a certain obligation to promote the institution's research. That undoubtedly influenced the way I used illustrations. But although I can now clearly see how several articles reproduced the visual clichés in popular science, my ambition as an editor was to develop a kind of journalism that was as critical as possible within the frames mentioned. Part of my goal was to reduce the distance between science and society; a distance that I find that the media have a tendency to maintain. To achieve this purpose, I found the portrait genre most usable, not only because of the freedom the genre provides for the writer, but also for the photographer. Here, the photographer could portray scientists as persons that the reader was invited to engage in a dialogue with, so to speak. An example is the portrait of Niels Christie, Professor of Criminology (Fig. 22).

I have argued that there are certain codes and established conventions guiding the use of images in popular science and science journalism. These codes may be accentuated in different ways, depending on such things as the newspaper's or the magazine's perception of its readers. However, I think there are 
a lot of unexplored possibilities for a different visualization in science journalism. One challenge is to portray science and science-related issues in a way that makes us see with "fresh eyes", so to speak, and invites the viewer to participate in questions connected to scientific research. But contributing to this by the use of images is certainly not a small challenge.

\section{REFERENCES}

Blum, Deborah, Mary Knudson (eds.) (1997): A Field Guide for Science Writers, New York: Oxford University Press.

Eide, Martin, Rune Ottosen (1994): "Science journalism without science journalists: notes on a Norwegian Media Paradox", Public Understanding of Science No. 3, pp. 425-434.

Fahnestock, Jeanne (1993): “Accommodating Science: The Rhetorical Life of Scientific Facts”, pp. 17-36 in Murdo William McRae (ed.): The Literature of Science. Perspectives on Popular Scientific Writing, Georgia: University of Georgia Press.

Fairclough, Norman (1995): Media Discourse, London: Edward Arnold.

Hornmoen, Harald (1999): Vitenskapens vakthunder. Innføring $i$ forskningsjournalistikk, Oslo: Tano Aschehoug.

Hornmoen, Harald (2003): „Forskningen har vist“: Roller og maktrelasjoner i forskningsjournalistikk“, pp. 182-199 in Kjell Lars Berge, Siri Meyer \& T.A. Trippestad (eds.), Maktens tekster, Oslo: Gyldendal.

Hornmoen, Harald, Gitte Meyer \& Peter Sylwan (2006): Fornuften har flere stemmer. Offentligheten, journalisten og forskeren, Oslo: Cappelen Akademisk Forlag.

Kjørup, Søren (1995): Hvorfor smiler Mona Lisa? - en bog om billeder og deres brug, Frederiksberg: Roskilde Universitetsforlag.

Kress, Gunther, Theo van Leeuwen (1990): Reading Images, Victoria: Deakin University Press.

Kress, Gunther, Theo van Leeuwen (1996): Reading Images: The Grammar of Visual Design, London: Routledge.

Ledin, Per (1997): „Med det nyttiga skola wi söka att förena det angenäma ...“. Text, bild och språklig stil i veckopressens föregångare, Lund: Institutionen för nordiska språk, Lunds universitet. 
Myers, Greg (1990): Writing Biology: Texts in the Social Construction of Science, Madison: University of Wisconsin Press.

Nelkin, Dorothy (1995): Selling Science. How the Press Covers Science and Technology, New York: Freeman and Company.

Veel, Robert (1998): “The Greening of School Science”, pp. 114-151 in J.R. Martin \& Robert Veel (eds.): Reading Science. Critical and Functional Perspectives on Discourses of Science, London: Routledge.

\section{THE FIGURES REFERRED TO}

Figs. 1, 2: from Scientific American, November 1982, copied from Myers (1990)

Fig. 3: $\quad$ from Hormones and Behavior, Vol. 18, 1984, copied from Myers (1990)

Fig. 4: $\quad$ from Scientific American, August 2002

Figs. 5, 6, 7: from Scientific American, April 2002

Fig. 8: $\quad$ from Scientific American, November 2002

Fig. 9: $\quad$ from Scientific American, June 2002

Fig. 10: from Scientific American, September 2003/ Illustrert Vitenskap $12 / 2003$

Fig. 11: from Illustrert Vitenskap 3/2000

Fig. 12: from Illustrert Vitenskap 12/2003

Fig. 13: $\quad$ from Nationen, August 2003

Fig. 14: from Aftenposten, 27.08.2003

Fig. 15: $\quad$ from $V G N e t t, 19.06 .2001$

Fig. 16: $\quad$ from $V G$ Nett, 05.12.2000

Fig. 17: $\quad$ from Scientific American, December 2002

Fig. 18: $\quad$ from Aftenposten, 03.05.2001

Fig. 19: from Aftenposten, 02.02.2000

Fig. 20: $\quad$ from Apollon $3 / 1996$

Fig. 21: $\quad$ from $V G$ Nett, 27.06.2000

Fig. 22: from Apollon 3/1997 


\section{Norwegian Abstract}

\section{„Visualisert vitenskap“. Billedillustrasjon i populærvitenskap og forskningsjournalistikk.}

\section{HARALD HORNMOEN}

Artikkelen utforsker hvordan forskning og forskere blir representert visuelt i populærvitenskap og forskningsjournalistikk. Den diskuterer hvilke kommunikative funksjoner og kulturelle betydninger visuelle elementer har i artikler om forskning. Ved å anvende begreper fra den visuelle grammatikken utviklet av Gunther Kress og Theo van Leeuwen, antyder forfatteren hvordan ulike typer modalitet blir brukt til å adressere leserne i populærvitenskapelige artikler i magasinene Scientific American og Illustrert Vitenskap. Forfatteren argumenterer for at de visuelle elementene konvensjonelt blir tilrettelagt med et pedagogisk siktemål, slik at de kan føre leserne fra en virkelighet som de antas å være fortrolig med og henimot mer abstrakt vitenskapelig kunnskap. Det er imidlertid markante forskjeller i måten Scientific American og Illustrert Vitenskap gjør dette på. Abstraksjonsnivået i Scientific American bidrar til å skape en identitet for magasinets lesere som en velutdannet og avansert sosial elite. Illustrert Vitenskap legger betydelig mer vekt på naturalistiske avbildninger. Forfatteren diskuterer videre hvordan fotografier, visuelle komposisjoner og verbaltekster virker sammen i en multimodal retorikk som er vanlig i forsknings- og helseartikler i norske aviser. 


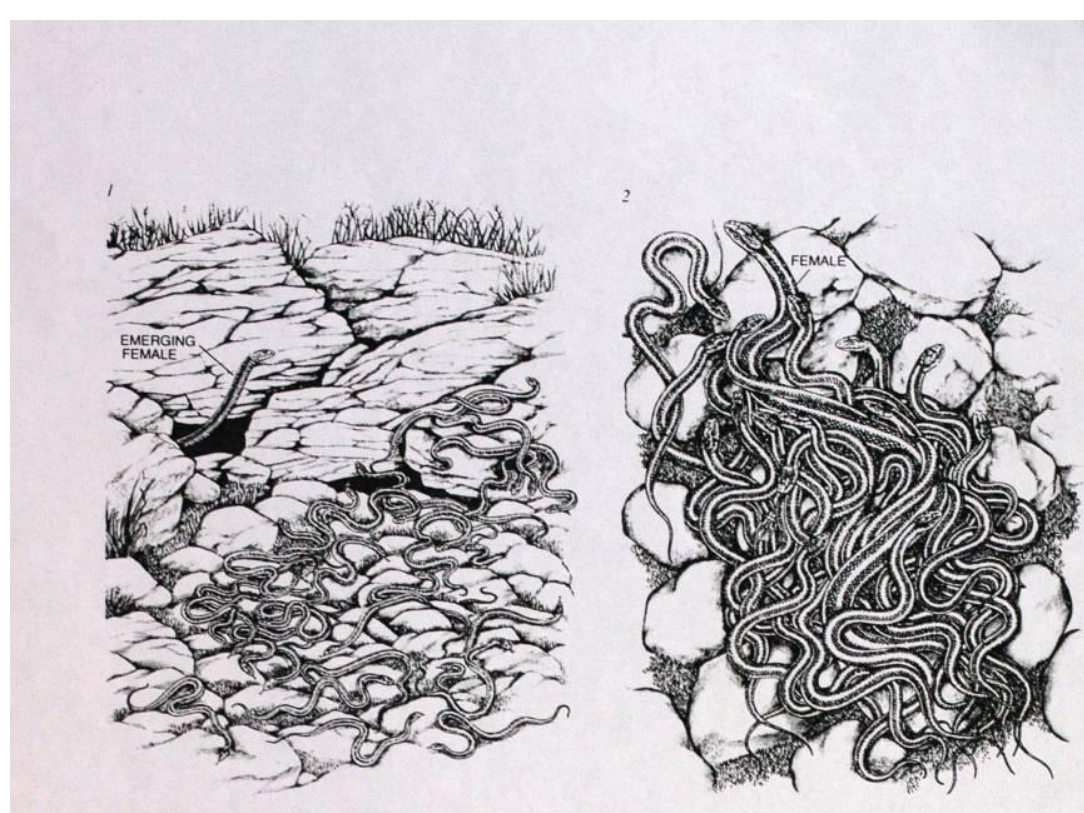

MATING BEHAVIOR of the red-sided garter snake is confined to
a short, intense springtime breeding season. For a period of from from which they emerge. Females emerge singly or in small groups
(o) Attracted by a pheromone (a messenger substance) on the back
of a female, as many as 100 males form a "mating ball" (2). One male three days to three weeks the males sun themedves near the
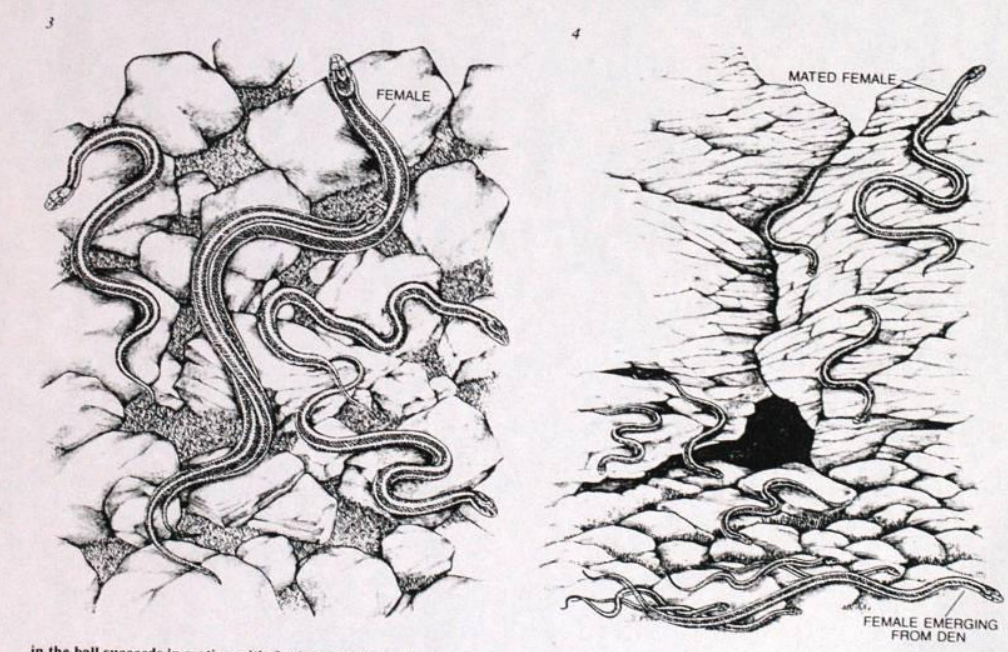

two hemipenes into her cloaca (her urogenital opening. The other
males immediately disperse (3). The of

tractive to males by a pheromone her mating partner conveys into
ber cloaca, immediately leaves the vicinity of the den. The males stay
near the den to await the emergence of another unmated fean s. Figure 5.6. A narrove in ustration by Patricia $V$. Wynne from -The

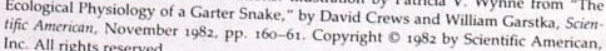




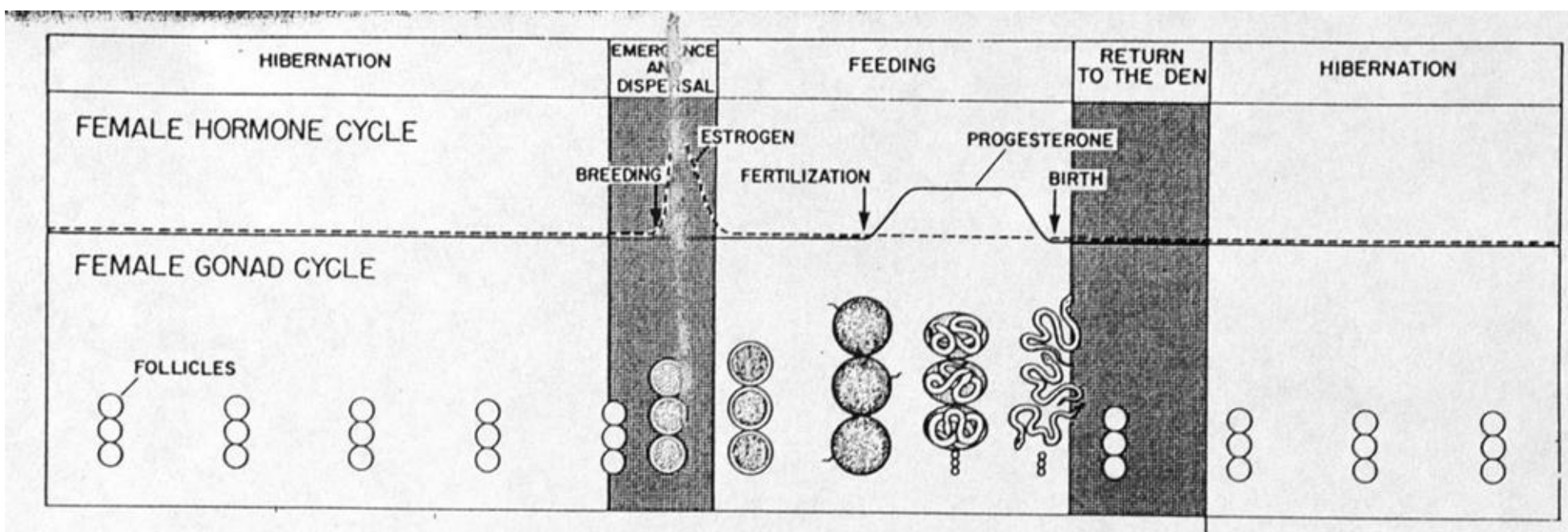

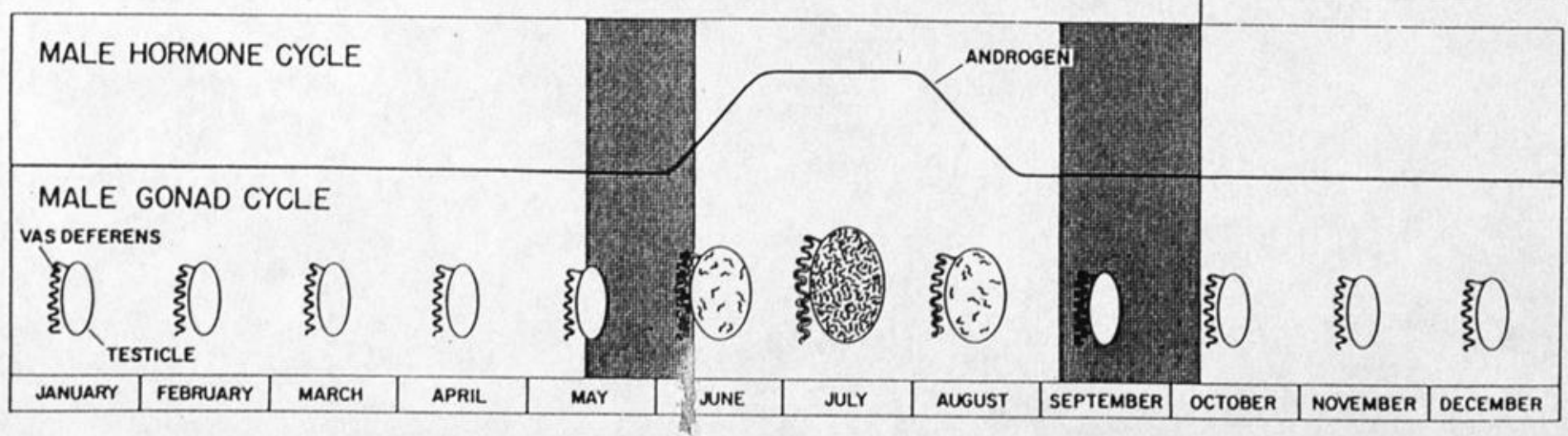

MISMATCH of physiology and behavior characterizes the reproductive behavior of the red-sided garter snake. From January through early May the snakes are in their den. In the female the blood level of the sex hormone estrogen is low, and the gonads (the ovaries) contain only small egg cells (follicles) lacking a yolk. In the male the blood level of the sex hormone androgen is low, and the gonads (the testicles) are small. The male's vas deferense, or sperm duct, is packed with stored sperm. The snakes emerge and mate late in May, Their gonads are still small and their sex hormones are still at an ebb. Only after mating are changes observed. In the female the mating causes the level of estrogen to rise. In response the eggs grow large and are filled with
yolk. In the middle of July the eggs are fertilized by sperm the female has stored fordix weeks. Then the level of progestorone, the pregnancy hormone, rises. In the male the level of androgen starts to rise at a time when the females have left the vicinity of the den. During the gummer the testicles grow large and produce the sperm the male will need the following spring. In August or early September the female gives birth, and by about the end of September botkg he male and the female have returned to their den.

Figure 5.7b. A Scientific American graph with iconic illustratikgs. Redrawn from an illustration by Patricia V. Wynne from "The Ecological Physiology of a Garter Snake," by David Crews and William Garstka, Scientific American, November 1982, pp. 162-63. Copyright 0 1982 by Scientific American, Inc. All rights reserved. 


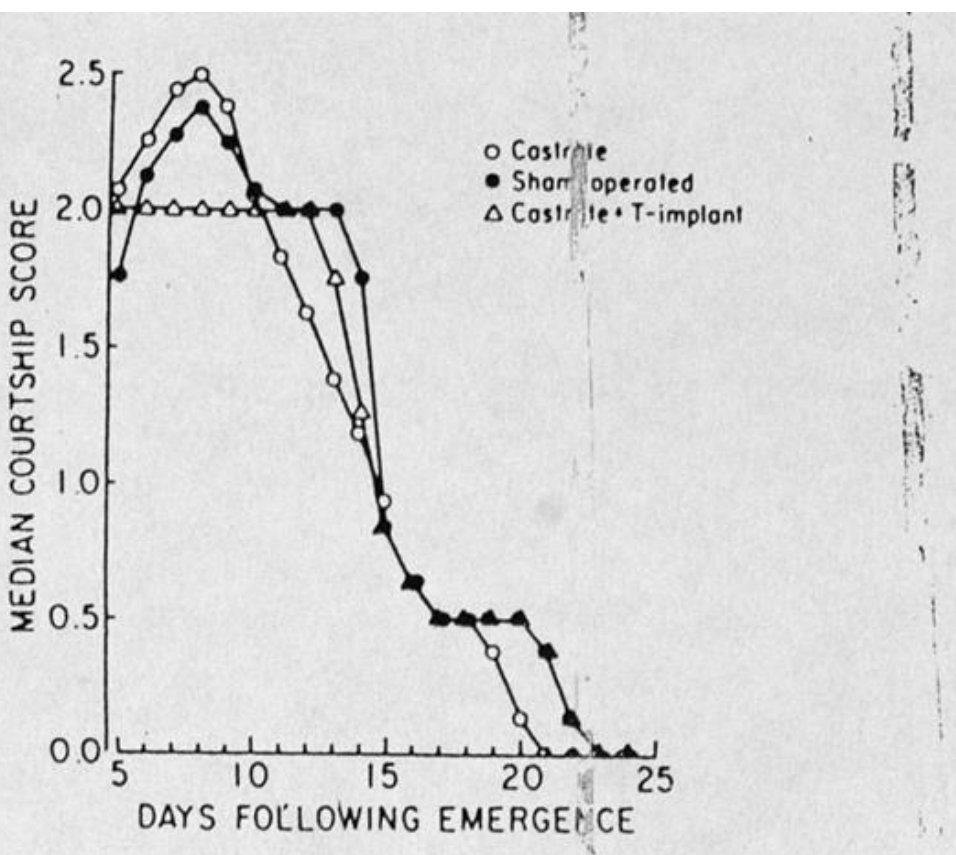

FIG. 1. Changes in courtship behavior of male red-sided garter snakes (Thamnophis sirtalis parietalis) on emergence from low-temperature dormancy. In nature following hibernation, or in the laboratory following low-temperature dormancy, courtship behavior initially is vigorous but then gradually declines in intensi $y$; males will not exhibit courtship behavior again unless exposed to cold temperatures. Depicted here is the decline in courtship behavior in males that were castrated, castrated and gives testosterone replacement therapy, or sham-operated in the fall prior to entering winter dc mancy.

Figure 5.7a. A Hormones and Behavior graph. Illustration from "Hormonal In of Courtship Behavior in the Male Garter Snake," by David Crews et al., Hormones and Behavior, Vol. 18, p. 34 . Copyright (c) 1984 by Academic ress, Inc. 
Phytoplankton's Influence on the Global Carbon Cycle

THE EARTH'S CARBON CYCLE can dramatically influence global climate, depending on the relative amounts of heat-trapping carbon dioxide $\left(\mathrm{CO}_{2}\right]$ that move into (yellow arrows) and out of [green arrows] the atmosphere and upper ocean, which exchange gases every six years or 50 . Plantlike organisms called phytoplankton play four critical roles in this cycle. These microscopic ocean dwellers annually incorporate about 50 billion metric tons of carbon into their cells during photosynthesis, which is often stimulated by iron via windblown dust (1). Phytoplankton also temporarily store $\mathrm{CO}_{2}$ in the deep ocean via the biological pump: about 15 percent of the carban they assimilate serties into the about 15 percent of the carton they ass mil the setics into the deep sea, where it is released as $\mathrm{CO}_{2}$ as the dead ceils decay [2]. Over hundreds of years, upwelling currents transport hec
gas and other nutrients back to sunlit surface waters. gas and other nutrients back to sunlit surface waters.
A tiny fraction of the dead cells avoids being recycled by becoming part of petroieum deposits or sedimentary rocks in the seafloor: Some of the rock-bound carbon escapes as $\mathrm{CO}_{2} \mathrm{~g}_{2}$ as and reenters the atmosphere during volcanic eruptions after millions of years of subduction and metamorphism in the planet's interior ( 33

Burning of fossil fuels, in contrast, returns $\mathrm{CO}_{2}$ to the atmosphere times faster (4). Marine phytoplankton and terrestrial forests cannot naturally incorporate $\mathrm{CO}_{2}$ quickly enough to mitigate this increase; as a consequence, the global carbon cycle has fallen out of balance, warming the planet. Some people have considered correcting this disparity by fertilizing the oceans with dilute iron solutions to artificially enhance phytoplankton photosynthesis and the biological pump.

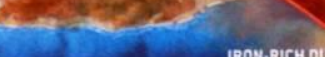
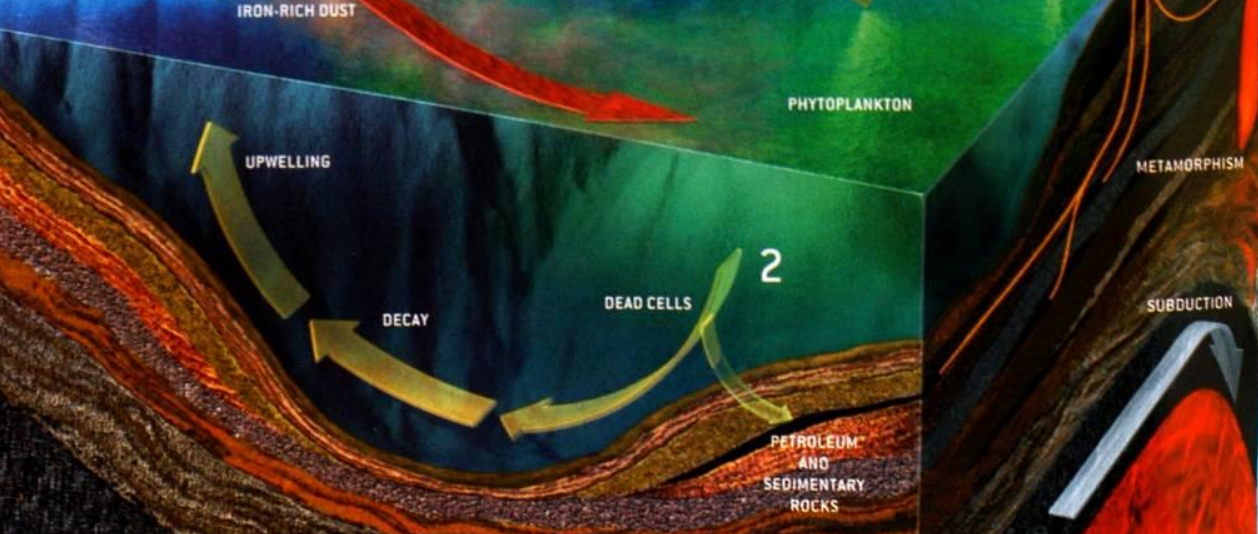


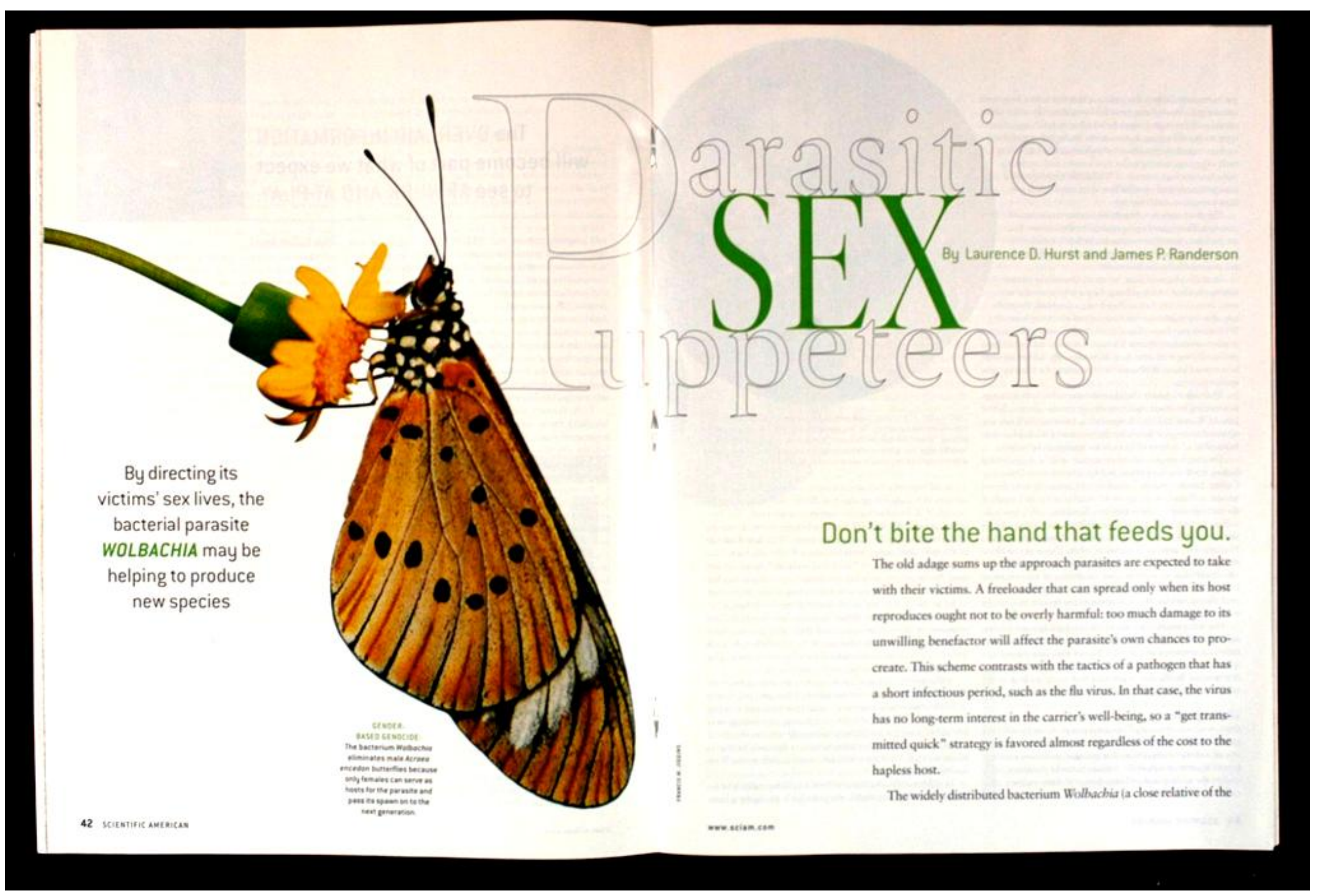




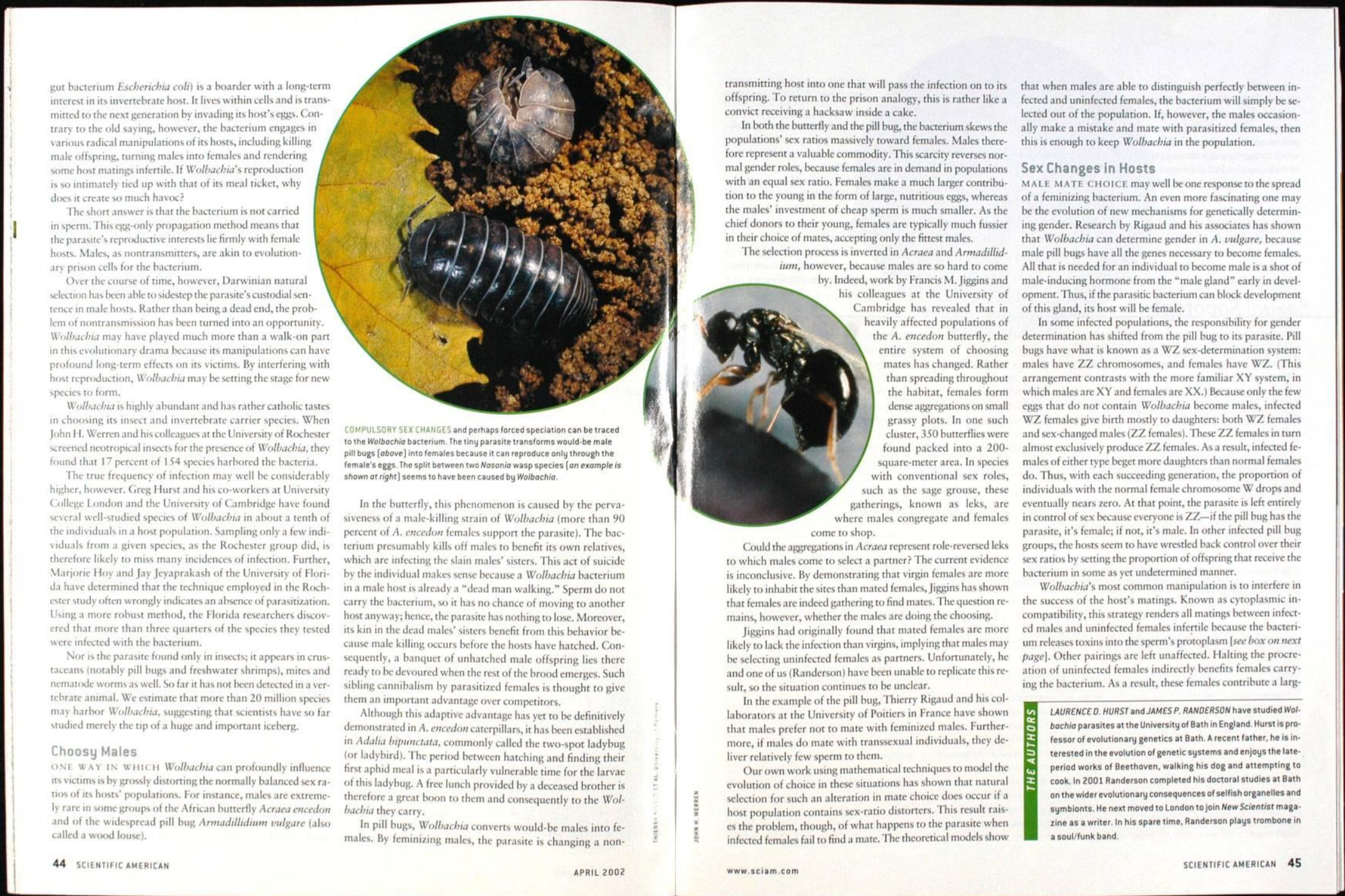




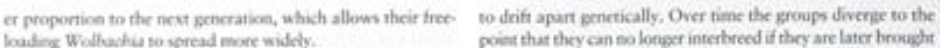

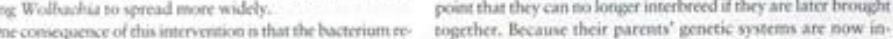

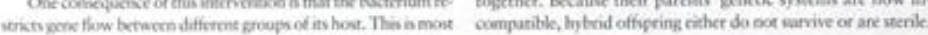

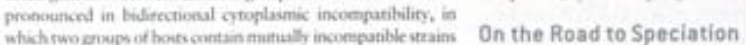

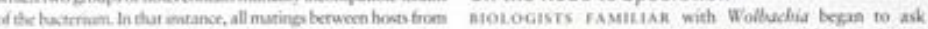

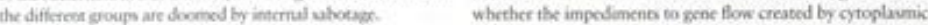

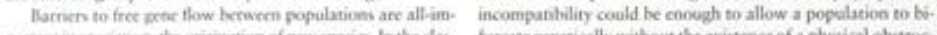

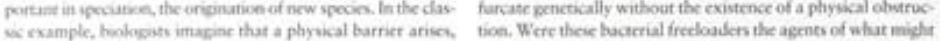

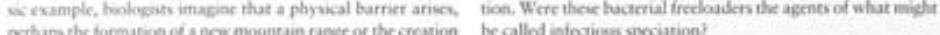

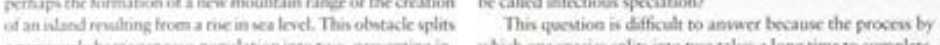

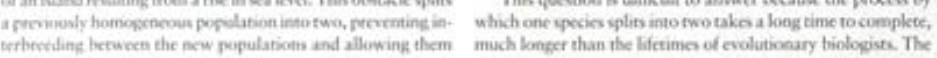

\section{Sexual Sabotage}

\begin{tabular}{|c|c|c|}
\hline 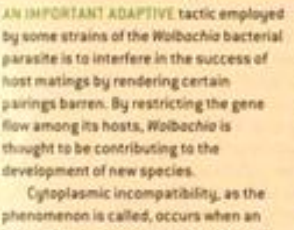 & 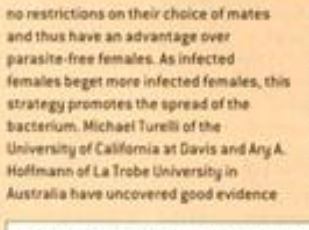 & 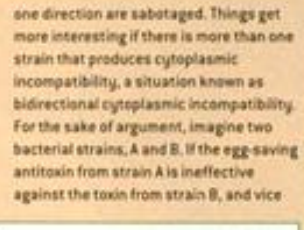 \\
\hline 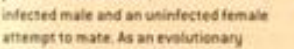 & 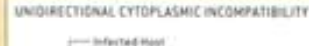 & \\
\hline 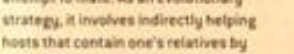 & - $0^{7} 80^{x}$ & \\
\hline & 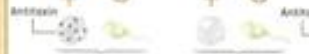 & $(8) \quad y$ \\
\hline 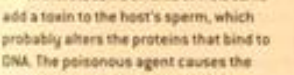 & 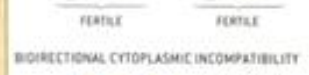 & $\overline{0}$ \\
\hline 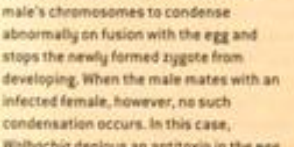 & 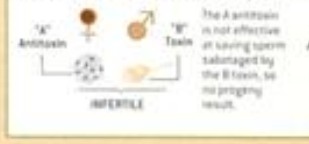 & 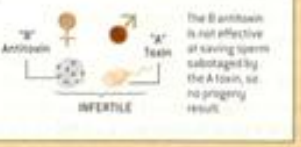 \\
\hline 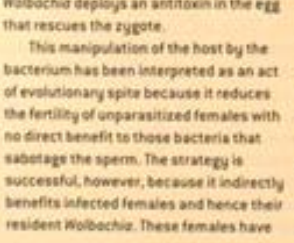 & 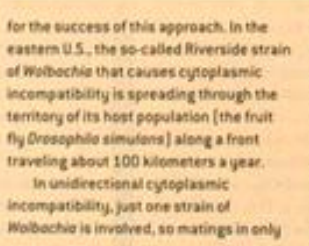 & 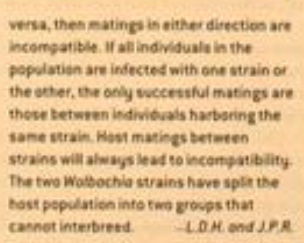 \\
\hline
\end{tabular}

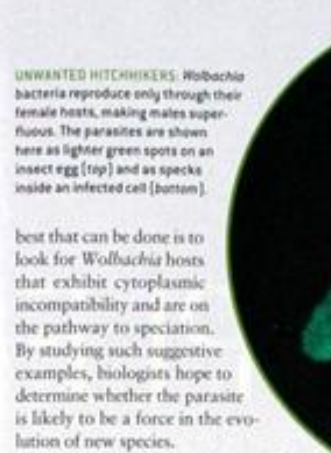

Two species of parat

prear to be near the end of such a ic mant

ere Nasomia vifripermis and N. gevialth, both in

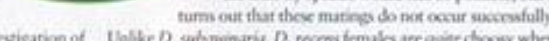

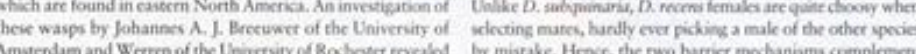

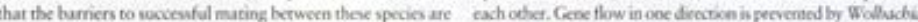

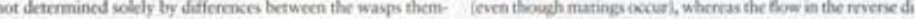

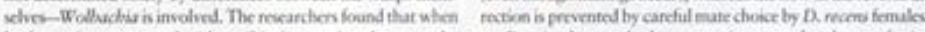

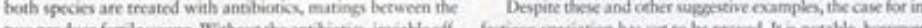

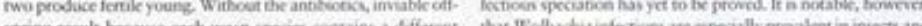

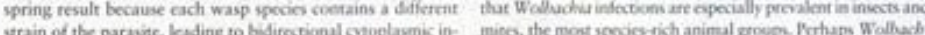

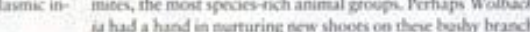

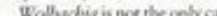

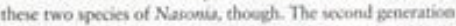

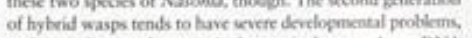
pertupe indicating that genceic dunges in the wasp' own DNA are now sufficient to keep the two spocis spute. Whether the parasite was imolind in promoting thin wivergence in tis pust

ta the case of the reperudective separation between N.ginambiand N. kangioumis, the story is different. These swo pur. asitic wasps have beces tawonomically determiend to be difite

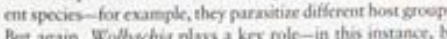

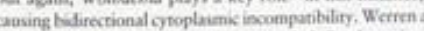
his Univenity of Rochester collewsoce Seth Bondenstein an

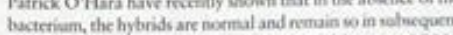
enencrations. Although genetis diverpence of the wasps' DNA

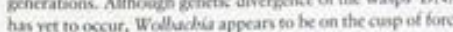
ing the endution of new specie-

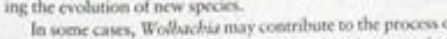

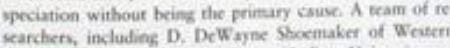

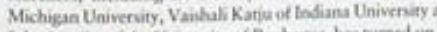
is of the tree of life.

Who's Running the Show?

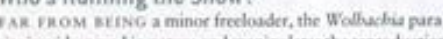

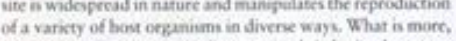
interpges by the tuccerium's honts to wade infective have seen

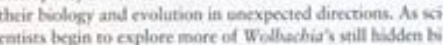
ology, we expect this influcential pawengers to have ofter war.

MORC TOEPRTER

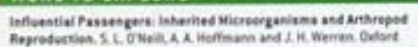
uniendy fiess. 1999 ?

Sen- hatiobistoring

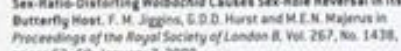

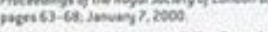

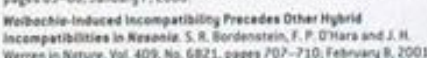

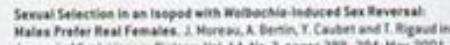




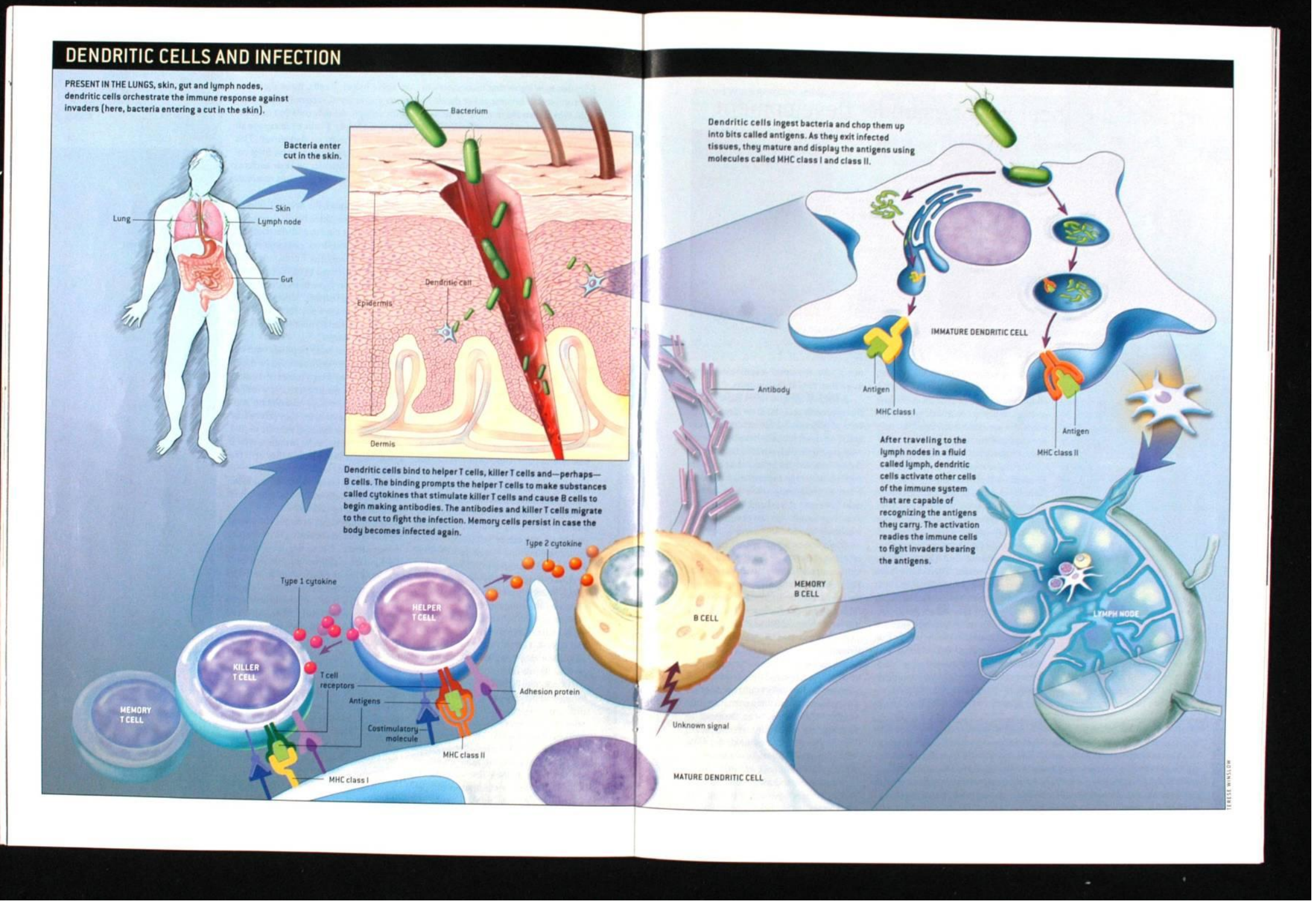


One AIDS Vaccine Strategy

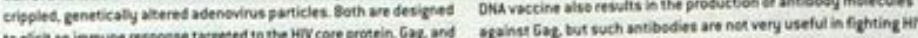

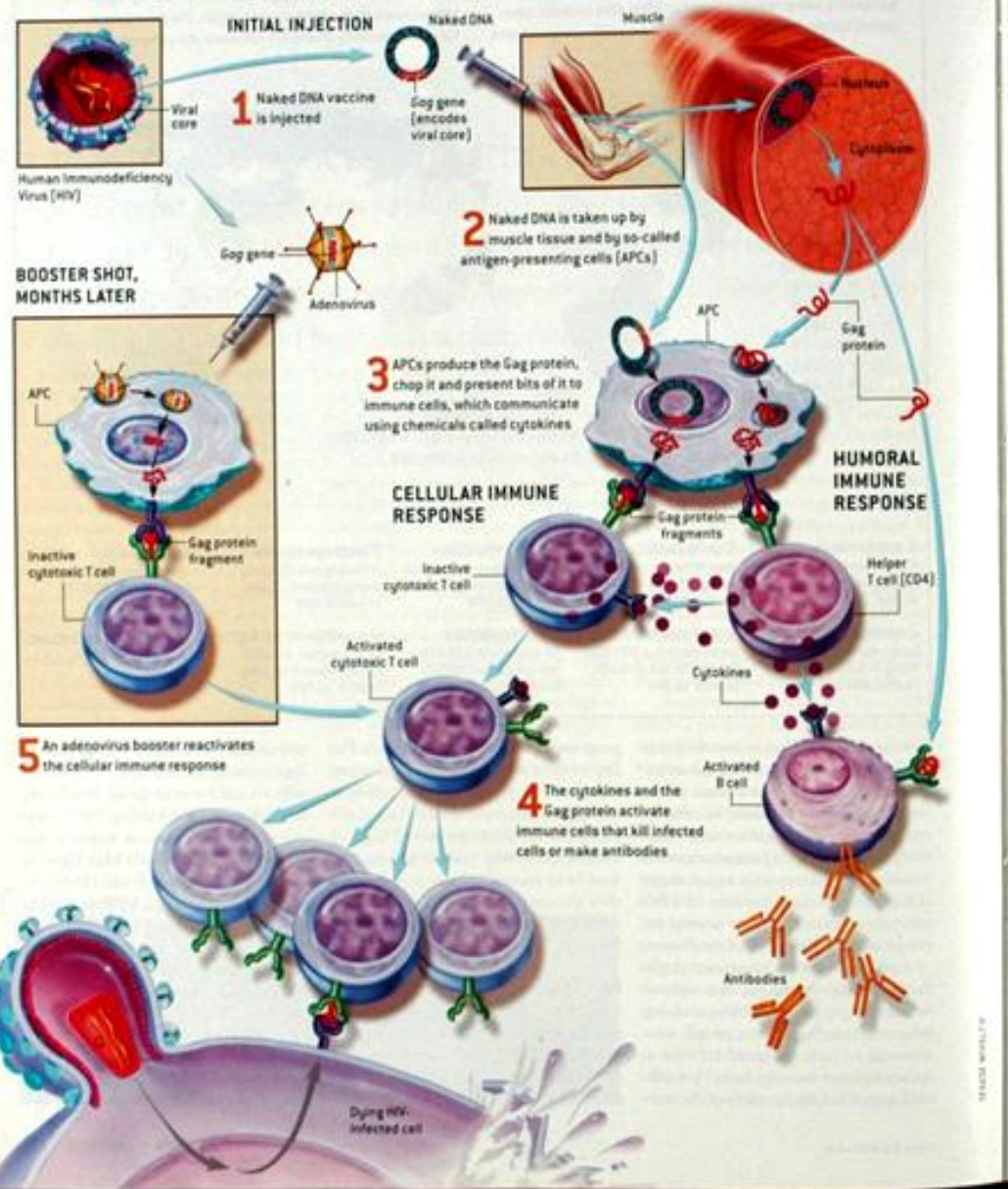

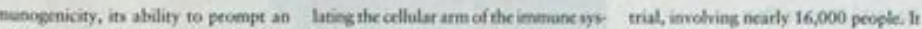

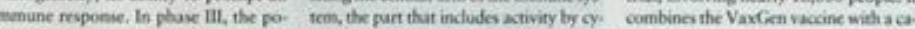

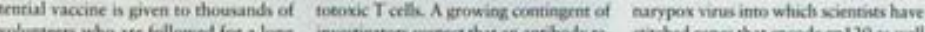

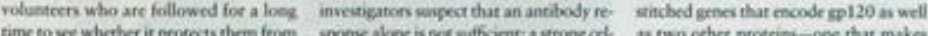

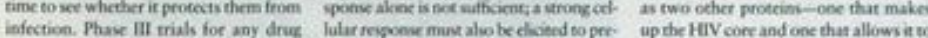

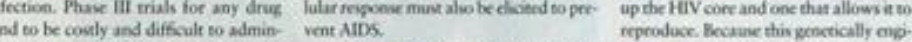

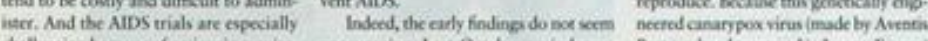

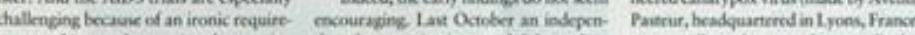

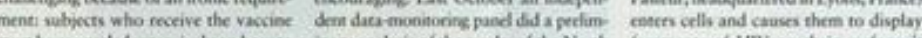

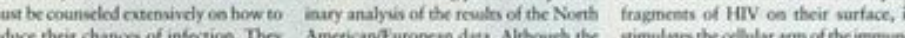

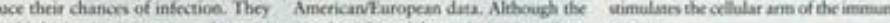
(a)

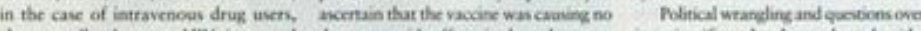

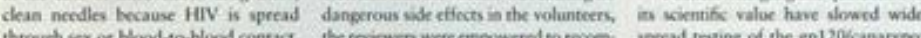
Results from the first large-Scale trial of an AIDS vaccine should become available at the end of this year.

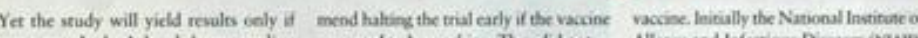

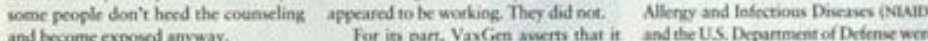

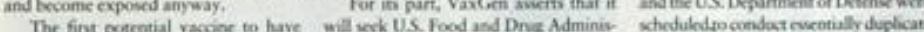

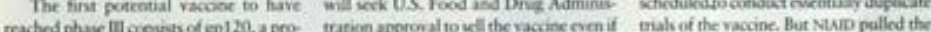

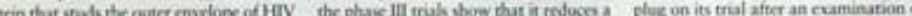

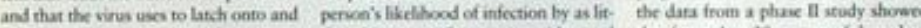

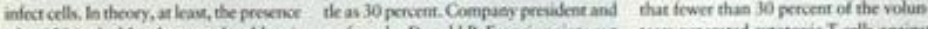

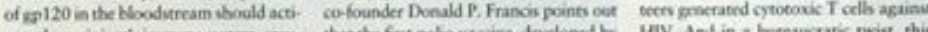

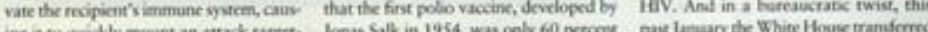

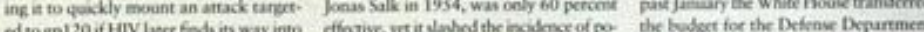

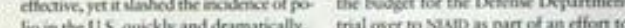

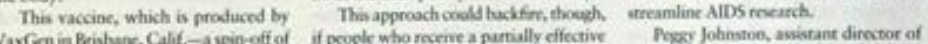

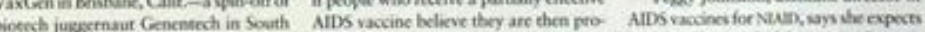

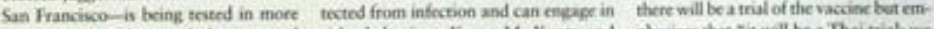

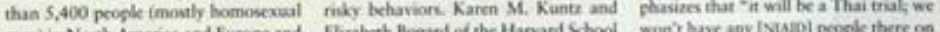

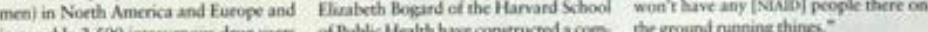

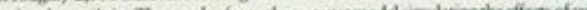

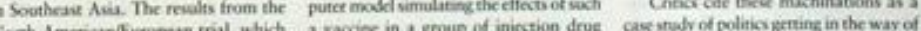

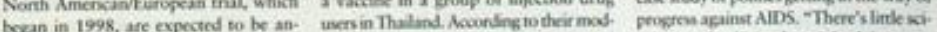

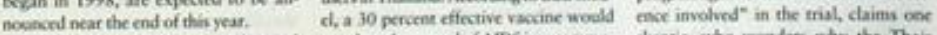

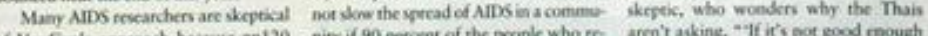

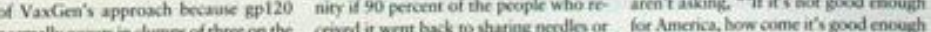

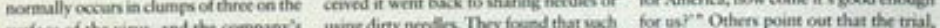

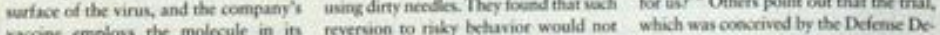

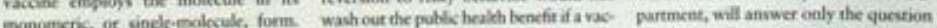

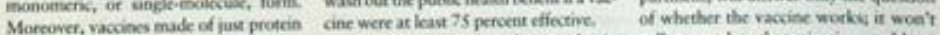

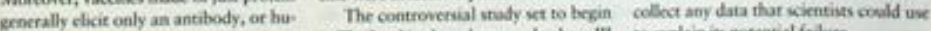
moral, response, without greatly stimu- in Thaland is also a largesale phase III co explain is poetential failure. 
- Genfeil gjorde oss intelligente

\section{- Barna våre får høyere IQ}

- Dyrene er klokere enn vi tror

- Klisterhjerne er ren teknikk

- Datamaskinen tar oss igjen om 20 ar

1

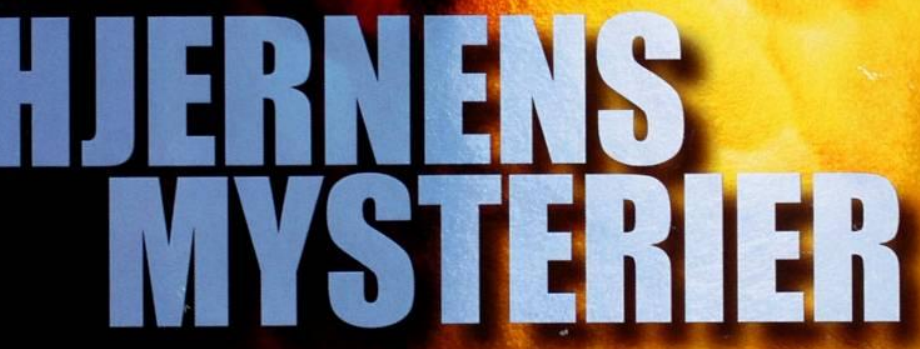

28
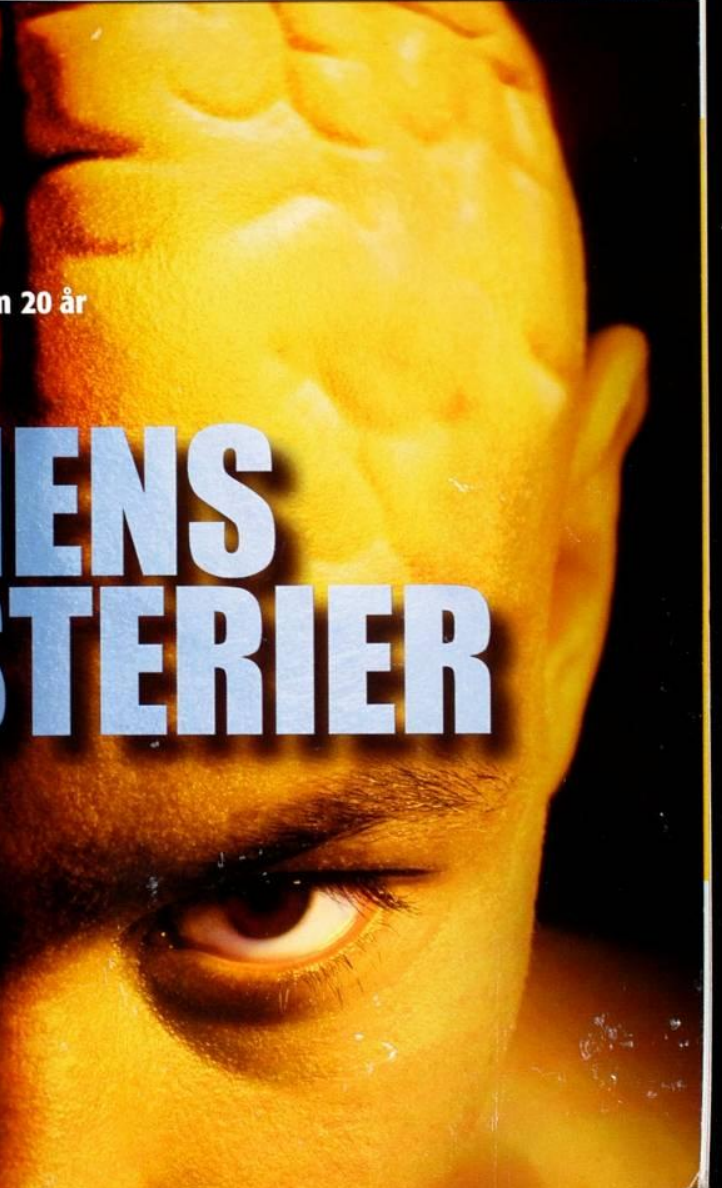

Ultimate Self-Improvement I New Hope for Brain Repair The Quest for a smart Pill Drain stimulis

Brain Stimulators

Taming Stress

Mind-Reading Machines Genes of the Psyche

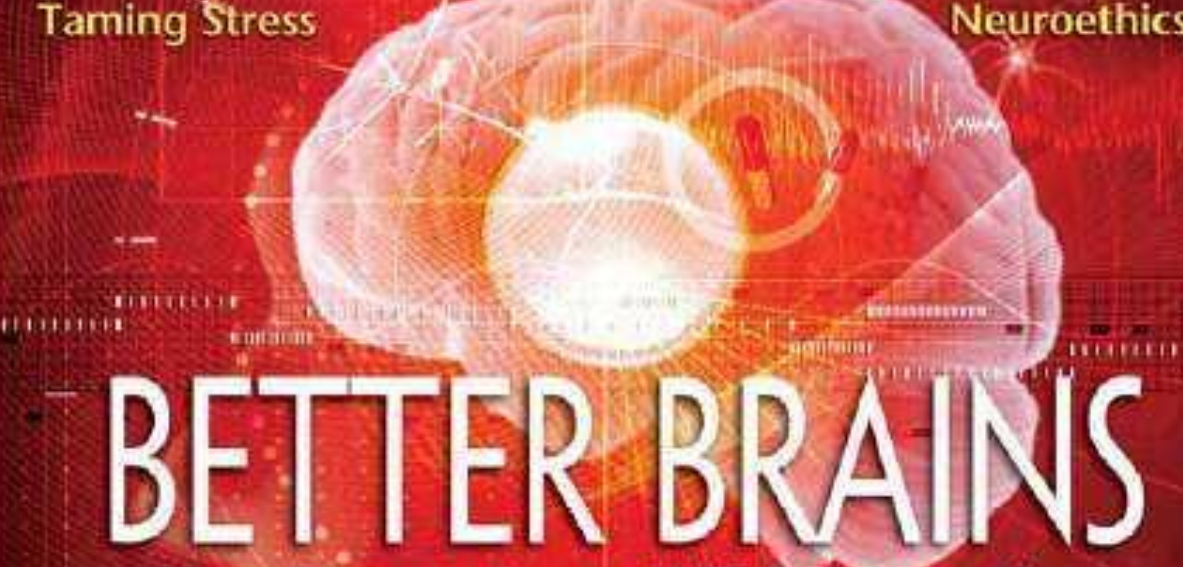

How Neuroscience Will Enhance You 


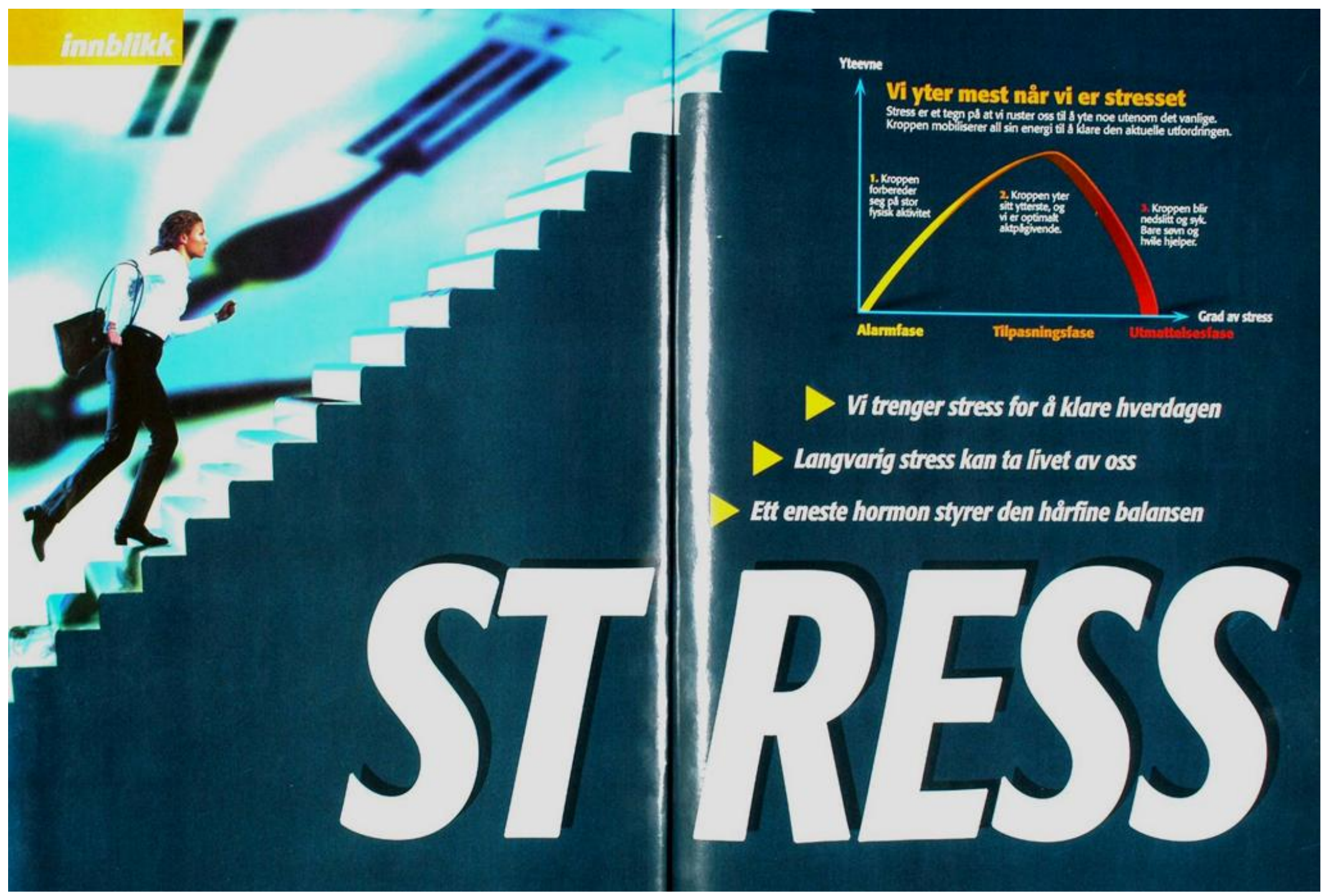




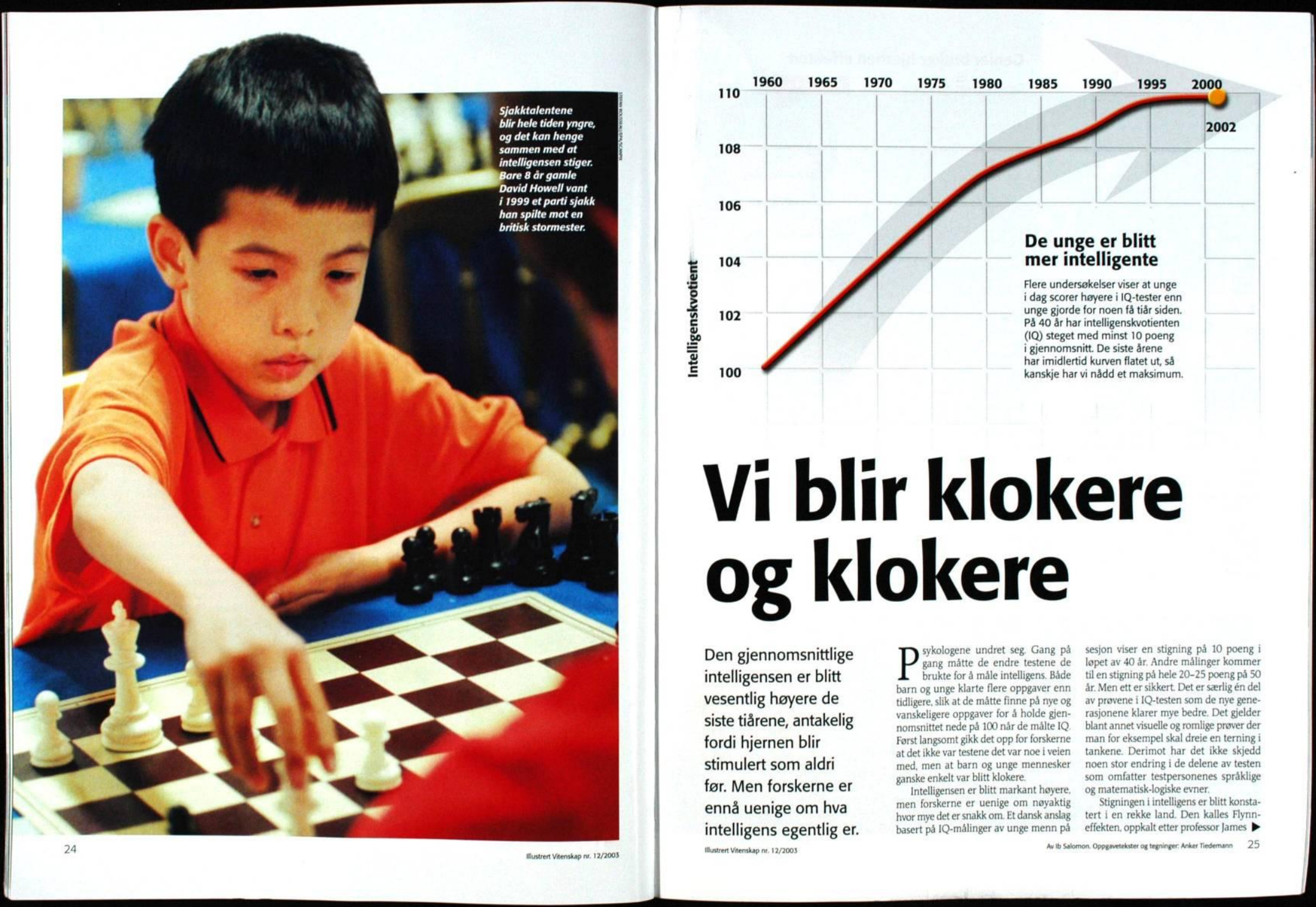


Sist planeten Mars var så nær Jorden som i dag, satt neandertalere rundt leirbålet. Neste gang vil være

om 284 år. Da har menneskene sannsynligvis baser på vår naboplanet.

\section{Mars nærmere enn på 60000 år}

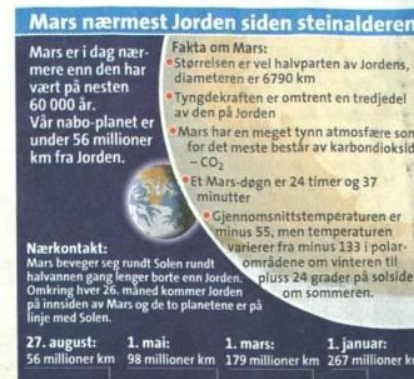

$$
\text { ROLFL. LARSEN }
$$

Historisk. Kom deg derfor
ut for ase den rode plane

teni dag. Den er historisk
tent

Klokken 11.51 er av-
standen til Mars obare

kilometer. Det er ca

60000 ár siden den rodé
planeten var sá nar Jor-

den Neste gang varr nabo-
planet og Jorden er like

nær hrverandre, vil være
2287. Da har menneskene

planeten! Nà má vi noye

oss med a se var kanskj
fremtidige utpost $i$ rom

- Mars vil verere syntis
-ed det blotte ove son

en intens lysende, rod

k2-tiden, beveger seg mot

sydvest, og er synlig frem
ii den forsvinner i mor-

genlyset, sier stipendiat
Knyt Jorgen Roed ode

gaard ved Astrofysisk in
stitutt ved Universitetet

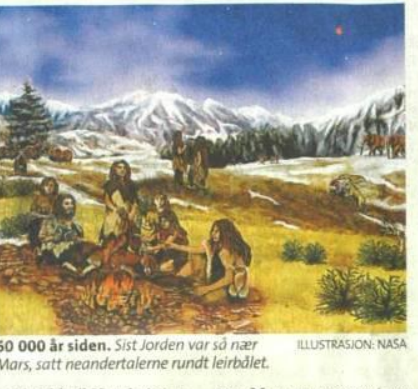

Mars, att neandert Jerden var sò nat

I kveld vil Norsk Astro-
omisk Selckap sto

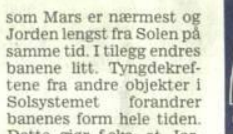

s.l.
vil vare fra kl. 23.30 t

Hvorfor skjer dette ná?

banenes form hele tider
Dette gior f.eks. at Jor.

tuns bane kan bli mer sir.

Bra på థstlandet

De beste observasionsfor-
holdene heri l landet blir

Sor-Norge i kveld. -Det

og Sorlandet. sier vakt
havende pà Blindern

statsmeteorolog $\begin{gathered}\text { Oolav } \\ \text { Erikstad. Ellers \& landet }\end{gathered}$

overskyet.
Men folk behover ikke

Men folk behover ikke
fortvile, selvom veret blif
dárlig nere steder i i das

lig, báde med det blotte

oye og i istjernekikkert ut
august og ogsá i begynn

elsen av september Me
en normal stjernekikkert

som gir 70 ganger for-
storrelse, vil du kunne se
Mars like fort som du ser

pá fullmánen med det
blotte oye forteller ast.

$\begin{array}{ll}\text { den med } 15.17 & \text { ars mel- den kan bil mer aviang } \\ \text { dist gang yar } & \text { Banene til Mars og Jor- }\end{array}$

988 og for det 11971 og den er for tiden slik a

1956. Denne gangen kom- neste nermote kommer
mer Mars enda iitt nem- - allerede- arr 2287, sier

ystemet gár i svakt av- Mars er over halvparten
unge baner rundt Solen.
sástor som Jorden, har en

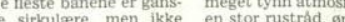

mer enn at avstanden til tig overnate. Den rode
Solen varierer med flere
fargen skyldes oksiderte

oillioner kilometer. For

dens avstand fra So
nellom 146 og 152
mill

Solen er ca. 228 million

av nye mystikk, Mens vi

ag vet at det ikke er- - el.
er har vert - smà gronne

nenn pá den rode plane

daget en rekke spor ett.
rennende vann. Til tross

Ir at Mars er langt mind-
eenn Jorden, har den en
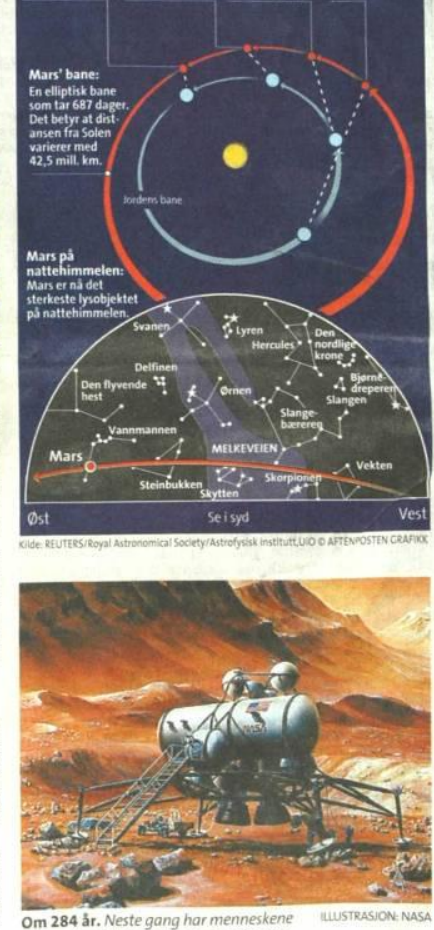

ar nesten samme dogn- tivt liv. En europeisk og to Ut i fra dette ser vi at re enn Jorden, har den en
Iars og Jorden kommmer del likhetstrekk: Den har

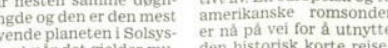

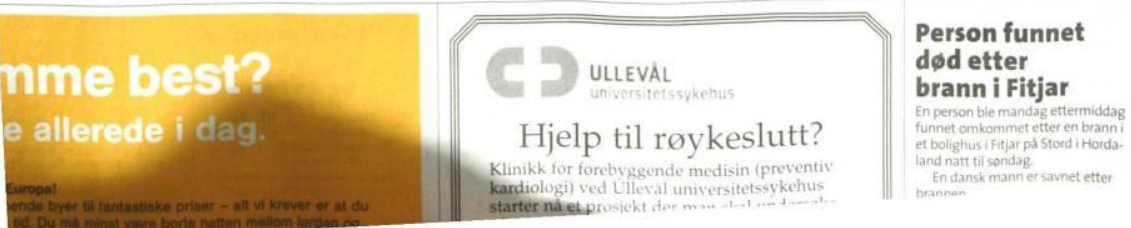


Siste syu dager Dagens VG Iips VG Hett Hovedsiden

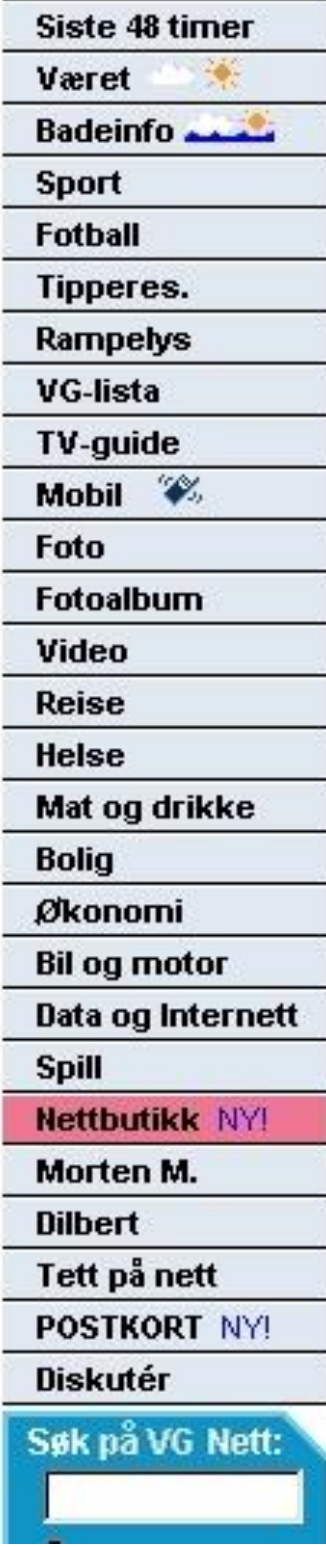

\section{Fremtiden blir kald og vGFOLGR} svart

Universets skjebne er omsider avslørt. Fremtiden blir kald, svart og uendelig.

\section{Tips en venn om denne saken! - Se dagens mest populære tips!}

\section{Av LINN SANDBERG SKARSTEIN}

Denne sensasjonen kom frem etter et av de lengste og viktigste eksperiment innen partikkelfysikk utfort noensinne. Resultatene ble kunngjort for en måpende skare av vitenskapsmenn verden rundt $i$ găr ettermiddag. Mange forskere har lenge hvilt på teorien om en såkalt «Big Crunchy - det vil si en tro på at alt i

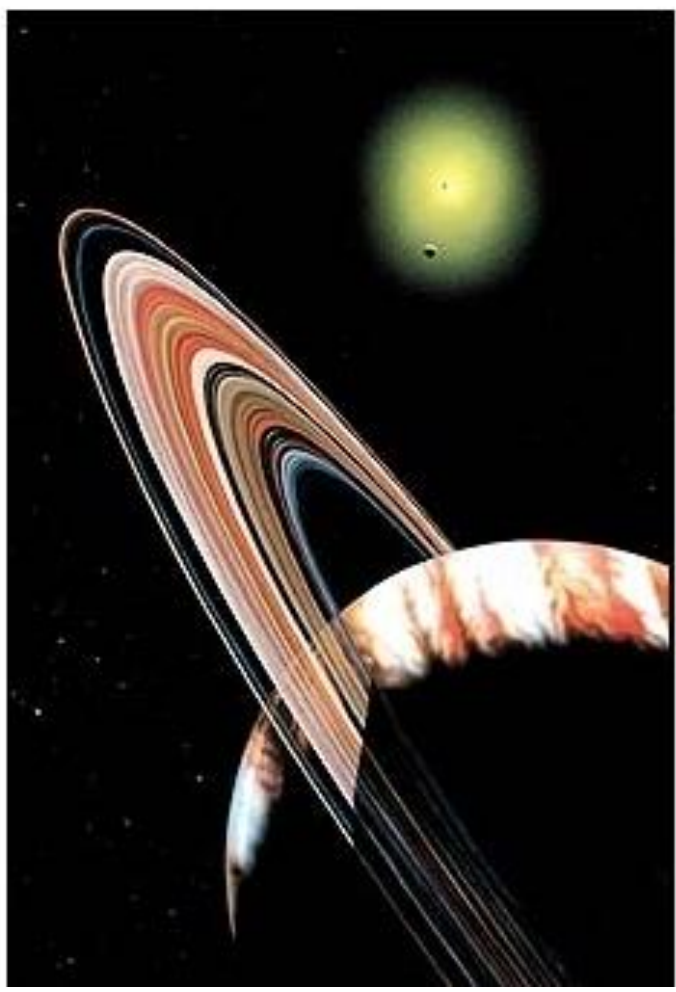

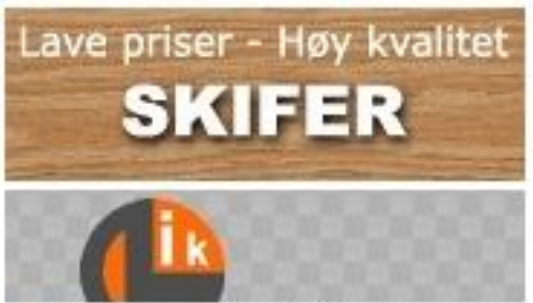

internettkatalogen.no

\section{Enkelt}

Raskt

Rimelig

\section{www.colorline.no}

SVAR \& VINN

- en reise for 2 
- glsie 010 inley

- Siste swu dager

- Dagens VG

- Iips VG Hett

- Hovedsiden

- Siste 48 timer

- Varet

Badeinfo

- Sport

Fotball

- Tipperes.

Rampelys

- VG-lista

- TV-guide

- Mobil " $\&$

Foto

Fotoalbum

Video

Reise

- Helse

- Mat og drikke

- Bolig

- Ø̋konomi

- Bil og motor

- Data og Internett

- Spill

- Nettbutikk NY!

- Morten M.

- Dilbert

- Tett pă nett

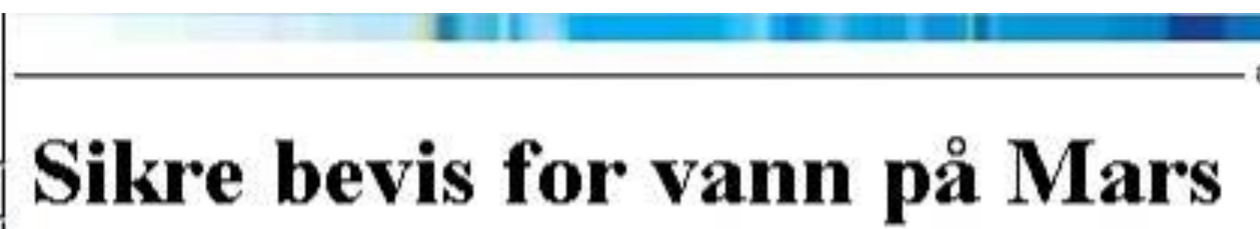

OSLO: For forste gang har forskere funnet sikre bevis for at det har eksistert store sjøer med vann på planeten Mars. Funnet setter fart $\mathrm{i}$ spekulasjonene om liv på andre planeter enn jorden.

a Tips en venn om denne saken! - Se dagens mest populære tips! tôn Se også văr bildespesial Vann pă Mars.

-Der hvor det er vann er det håp om liv, sier forsker Knut Jorgen Røed $\varnothing$ degaard ved Astrofysisk Institutt ved Universitetet i Oslo til NTB.

\section{Store mengder vann}

Det er høyoppløselige bilder fra det amerikanske romfartøyet Mars Global Surveyor som avslorer at Mars har lag på lag med sedimentere bergarter, som vi kjenner dem fra jorden. Dette betyr sannsynligvis at det for flere milliarder àr siden eksisterte store mengder vann på planeten.
Lave priser - Hoy kvalitet

\section{PARKETT}

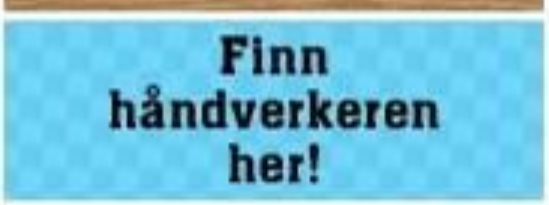

\section{mine \\ linser}

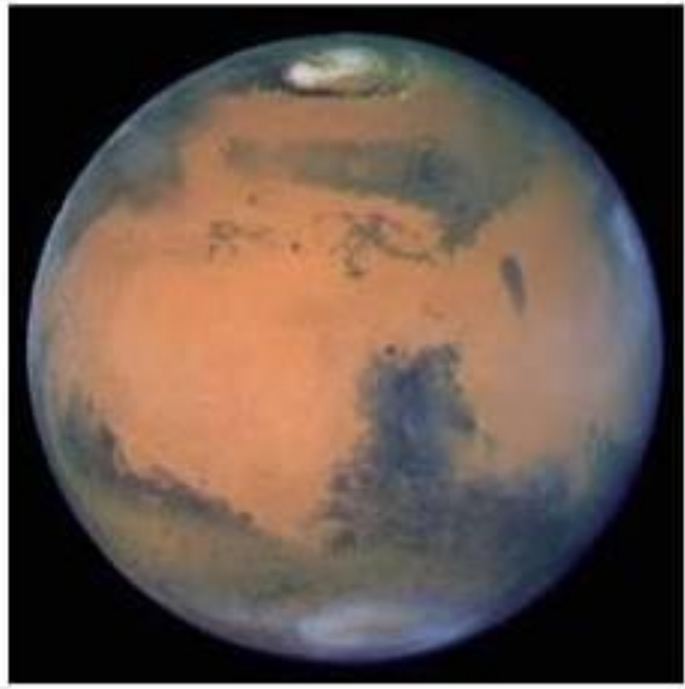

DEN RODE PLANET: Dette bildet av Mars eller *Den røde planet \$ som den ogsă kalles, er tatt av NASA Hubble Space Telescope i mars 1997. Na har forskerne funnet bevis for at det har vaert sjøer pă planeten. Foto: AP
SVAR \& VINN

- en reise for 2 


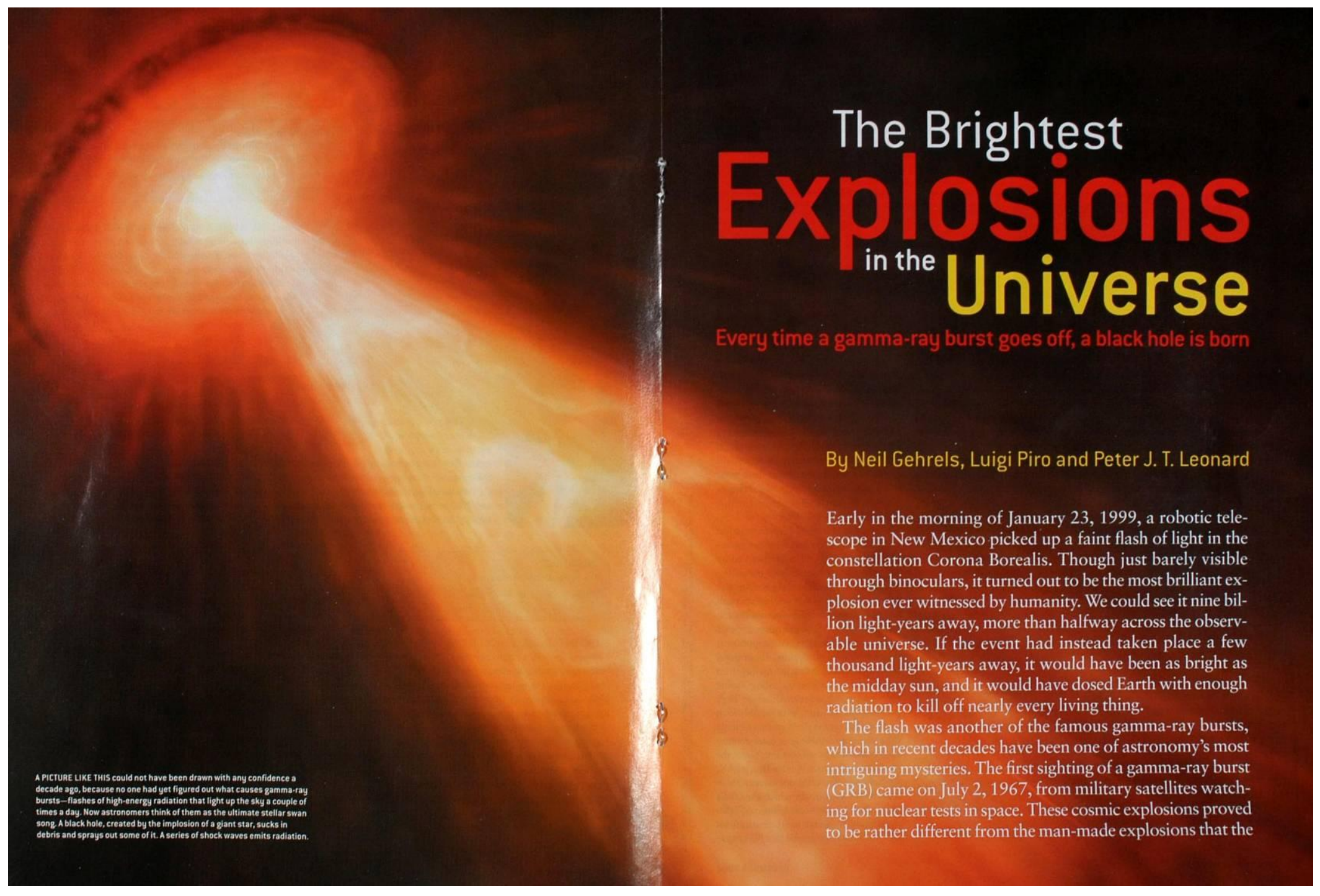




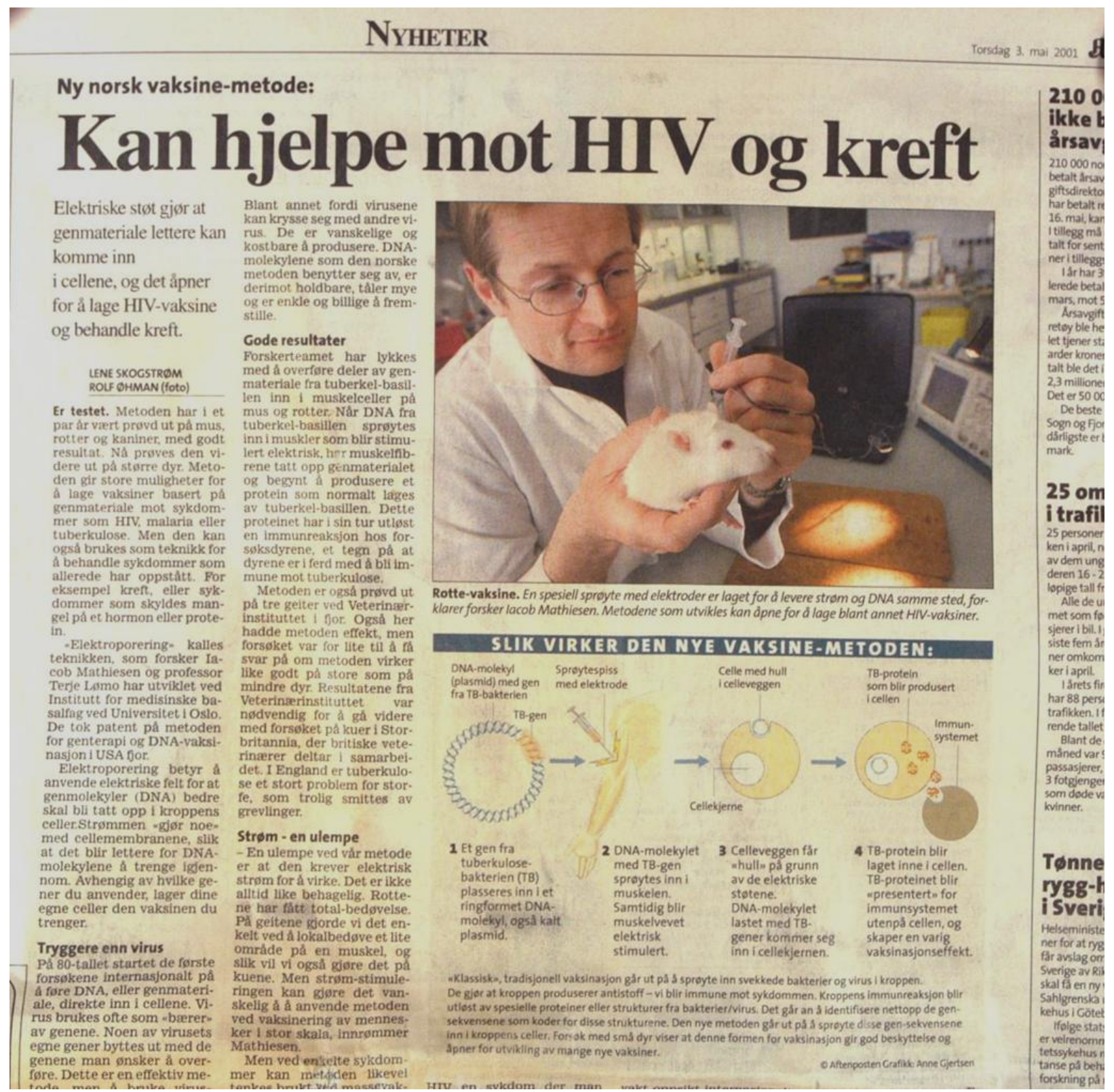



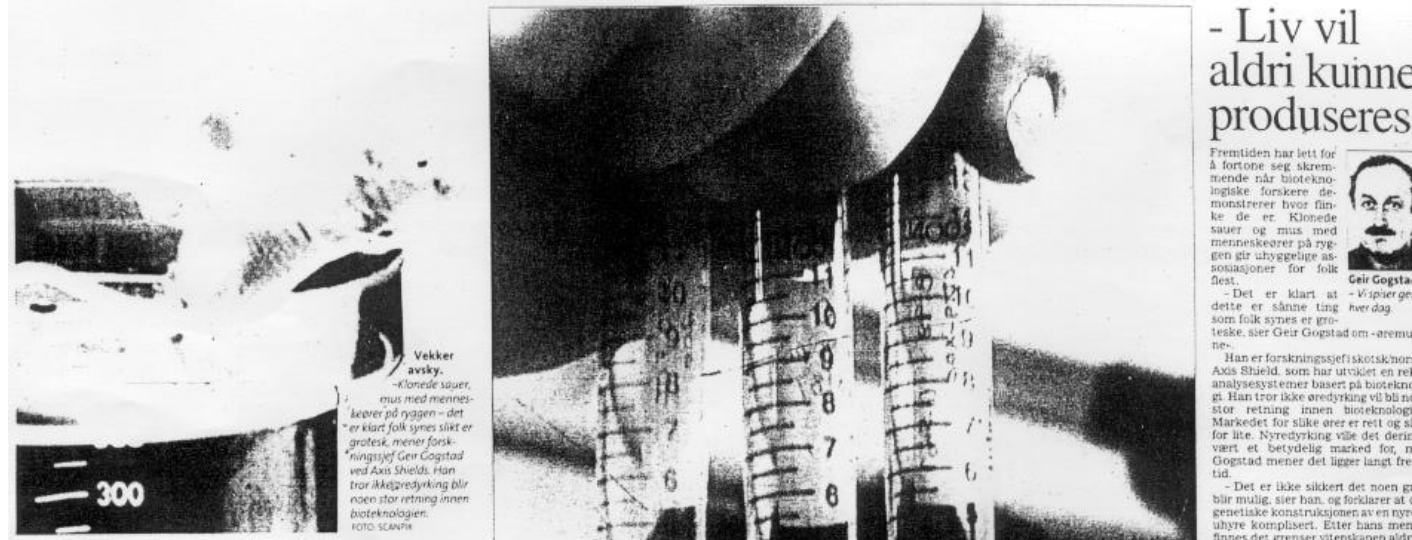

Norsk bioteknologi henger etter

Ett av få. Diatec slår bioteknologi og Internett ién smekk. Det lille selskapet er blant de fả $i$ Norge som satser pa en av verdens fremste vel.
utradisjonelt distribusjonsapparat.

Naturlige grenser. Bioteknologi fremstår ofte som skremmende: Mus med menneskeorer og kionede dy Men forskningssjef Geir Gogstad tror naturente
grenser som teknologien ikke kan passere.

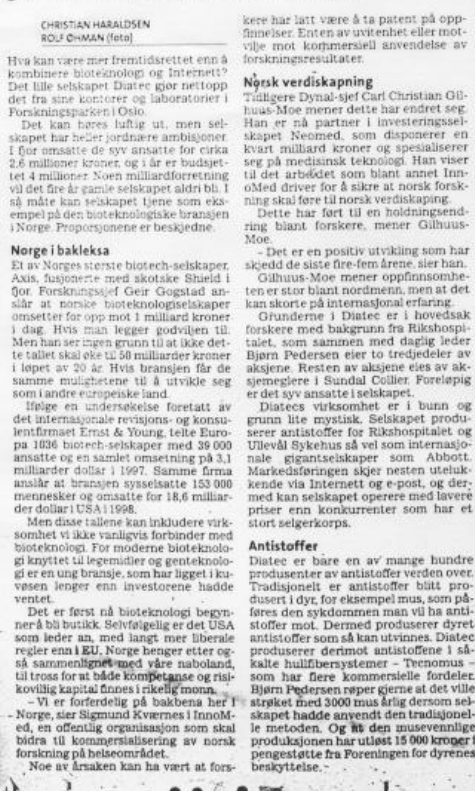

I. mint

(1)
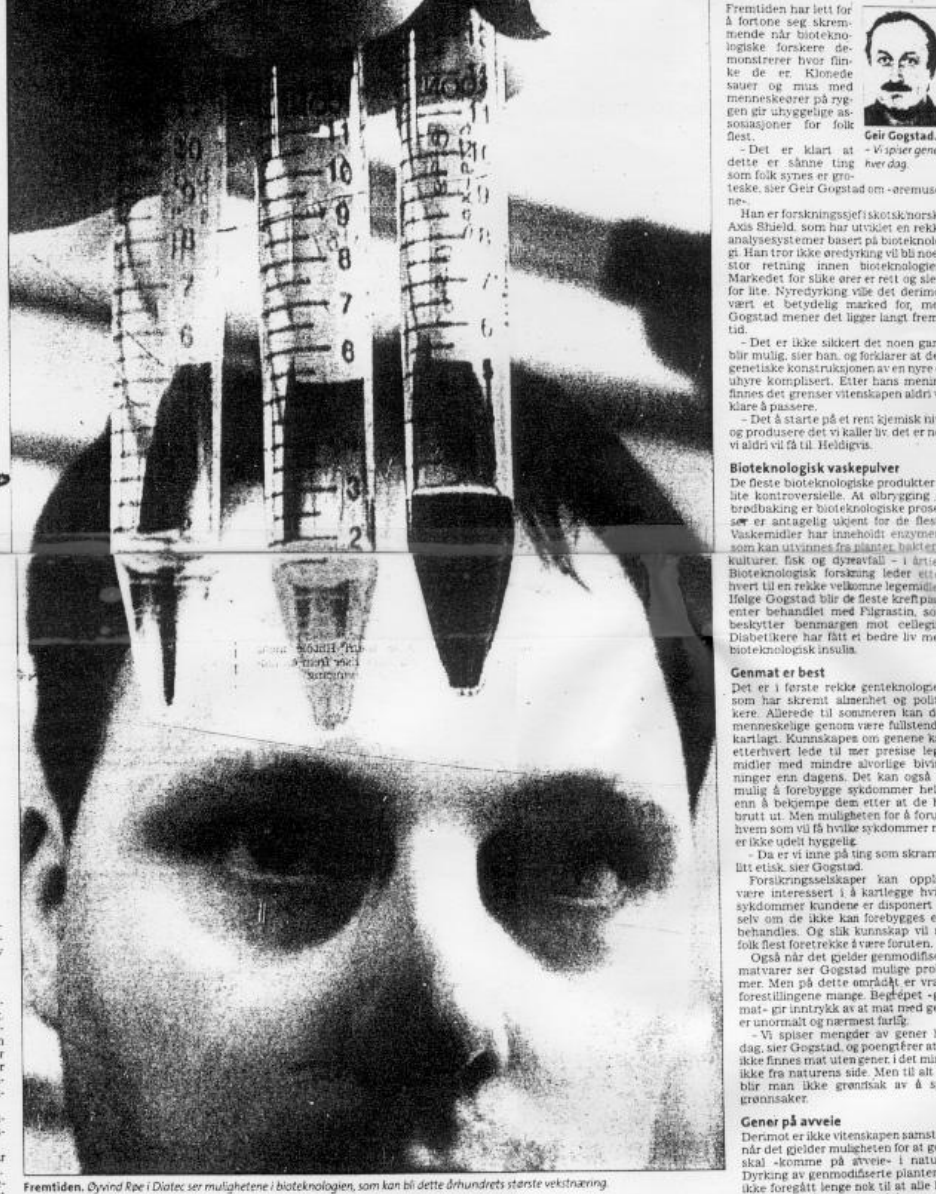

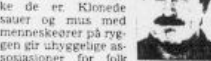

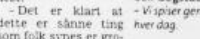
$=11$ (1) at $\frac{\pi}{5}$

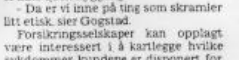

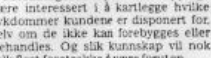

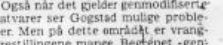

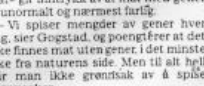

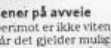
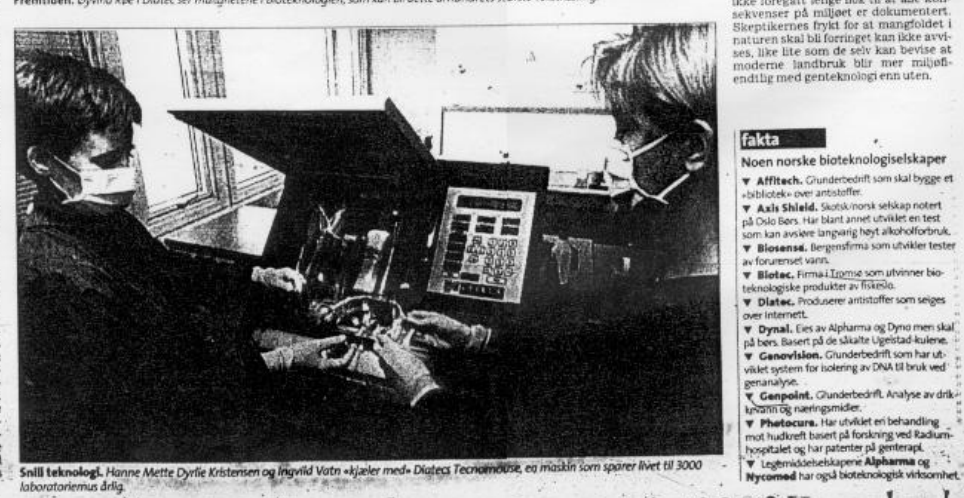


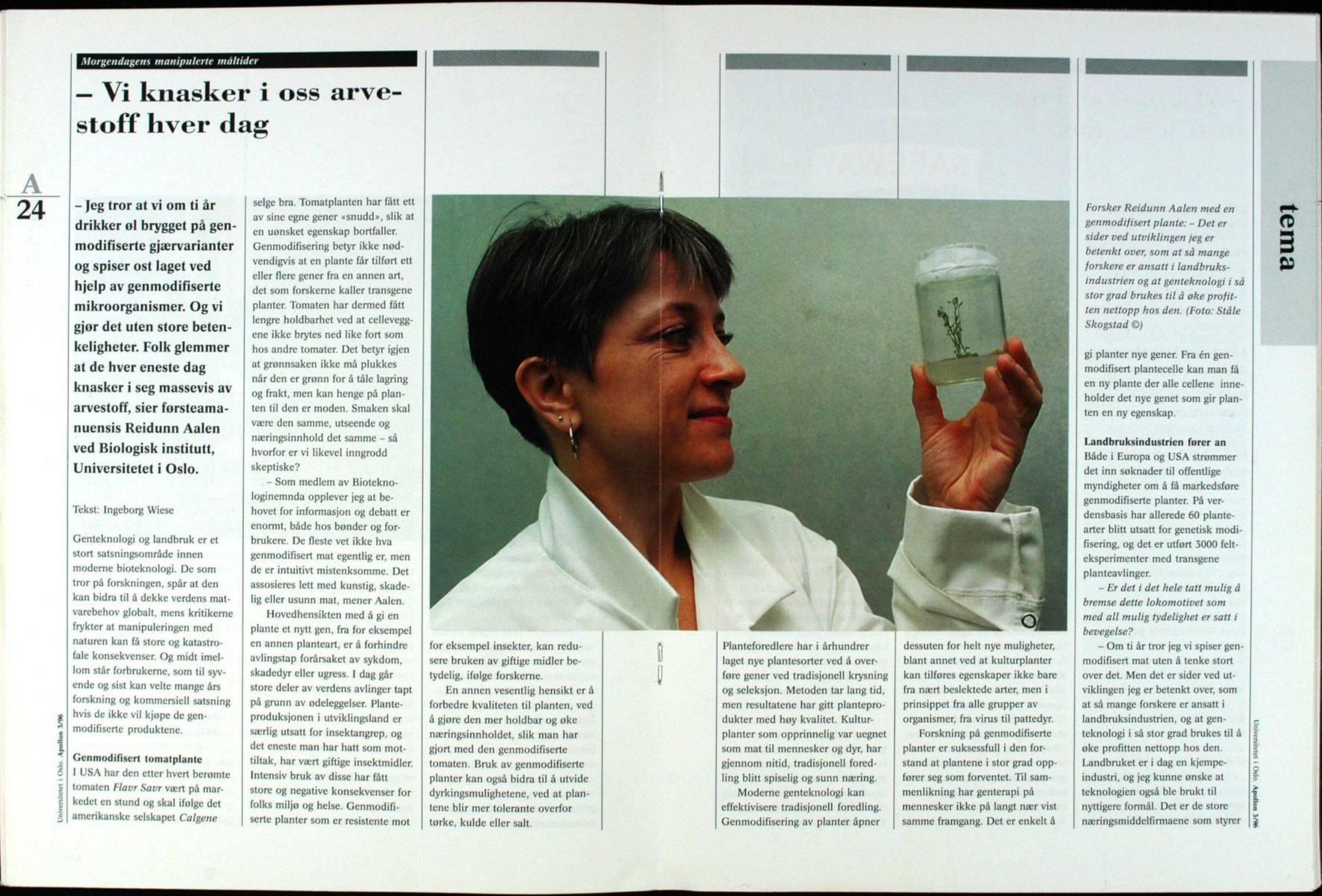


Eil Reediger Vis Fạvoritter Verktøy

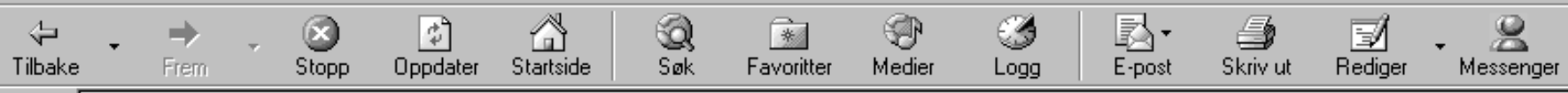

Adresse / 10 http://www.vg.no/pub/vgarthbs?artid=9954790

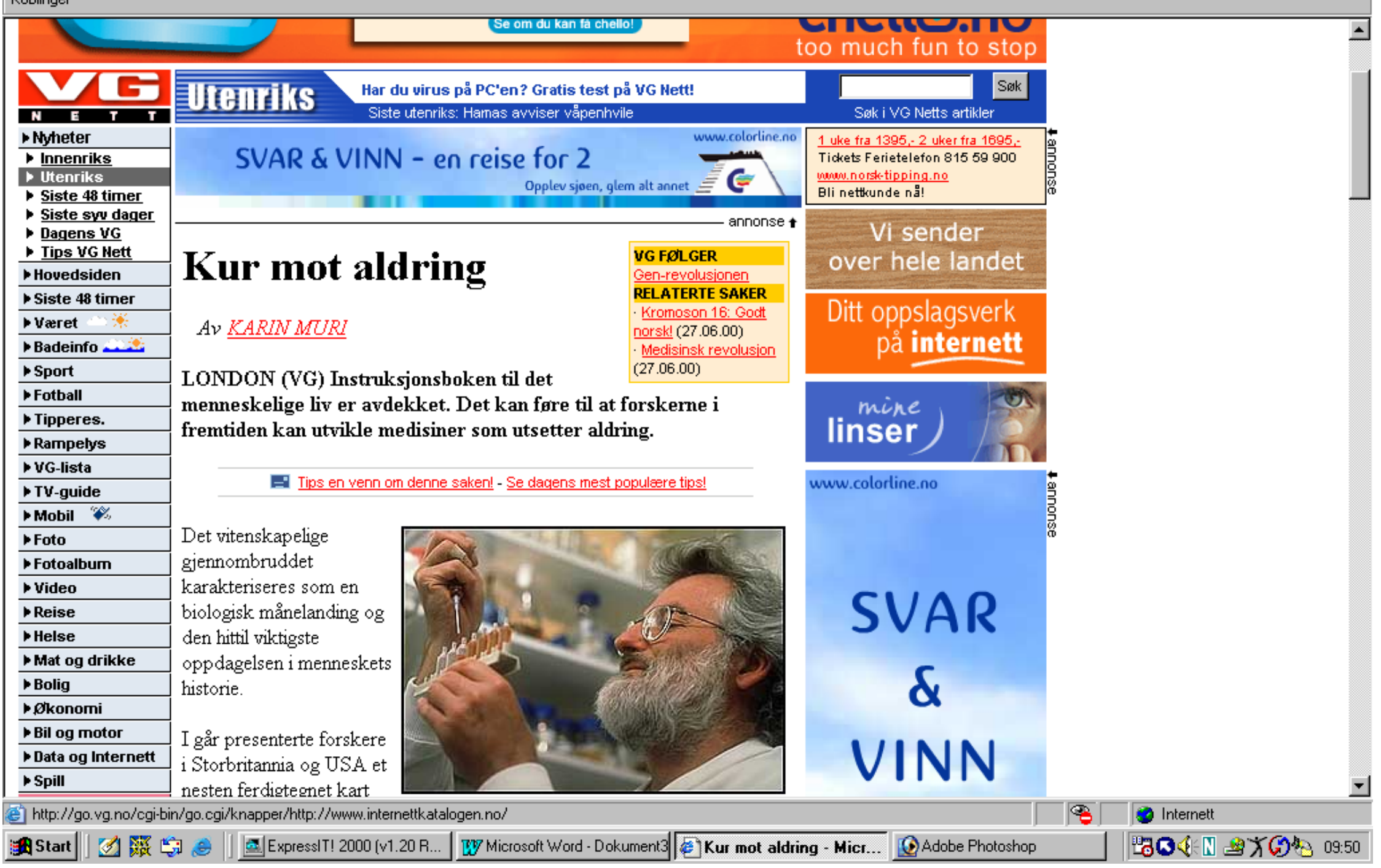




\section{- Gi meg et monster!}

10

Selv om jeg ferdes sammen med mange som regnes som fullstendig umulige, har jeg aldri mott monstre. Du kan se monstre i folkeeventyrene og i mediene, men gi meg et ordentlig monster,

da! Det er merkelig at jeg aldri kan møte et.

Tekst: Marianne Tonnessen

-1 de fleste relasjoner synes jeg de er mulig á ná fram til den andre o snakke sammen pá en noenlunde rimelig máte, sier Nils Christic. - Det á skape bilder av den
andre som farlig og ond, sperrer andre som farlig og ond, sperrer
for muligheten til à fá i gang en Tor mulfig
samtale.

samtale.
Vi er i gang med en samtale pà hans kontor. Christie har vert ansatt som professor $i$ kriminologi ar. I lopet av denne tiden har han ogsả rukket á bli kjent for mange kontroversielle utspill imediene. Men han oppfatter ikke seg selv som kontroversiell:

Jeg synes jeg er noksá fredelig og grei, og at det som oppfattes som kontroversielt, er nesten selvfolgelige observasjoner. Hva slags utspill tenker du pá? - Du har jo allerede for lenge siden gatrinn for a legalisere don med insulin, du er sheptse til integrering av innvandrere og hevder at ghettoer har fordeler, du har kritisen psykiatrien

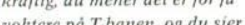
corst narkotibapolitith er futtstendig feilslàtt. Og du har gitt ut boker med titler som for eksempe "Hvis skolen ikke fantes". - Det siste er jo bare en enkel betraktning om hvordan det er. Jeg synes det er mer forbausende at det ikke er selvinnlysende for andre at skolen har en vesentlig oppbevaringsfunksjon i samfunnet, og at den er bygd opp sili den passer best for over- og tvilsomt à snakke om narkotika når man holder tobakk og alkohol
utenfor, og at man burde hindre at utenfor, og at man burde hindre unge mennesker dor hvis de er fanget inn i farlige livsiormer. A dette er jo svart enkelt, og jeg onsker ikke à skape kontroverser. den den art man kan giore det pa - Metadonsaken er en god illustrasjon pă dette: Hvis det kom en virus som serlig rammet den som arbeidet foran en data- - Jeg synes ikke det er morsom Jeg vet ikke om skjerm, da ville à vare en offentlig person, jeg er det ville vart helt samfunnet mobi- noksà sjenert. det gielder folk i sterkt truede livssituasjoner som bruker heroin, vet vi ogsá at noe kan giores. Det er pávist at deres dødelighet blir betydelig mindre hvis de fár metadon. Og det er en billig Mering Men langtkomne narkotika
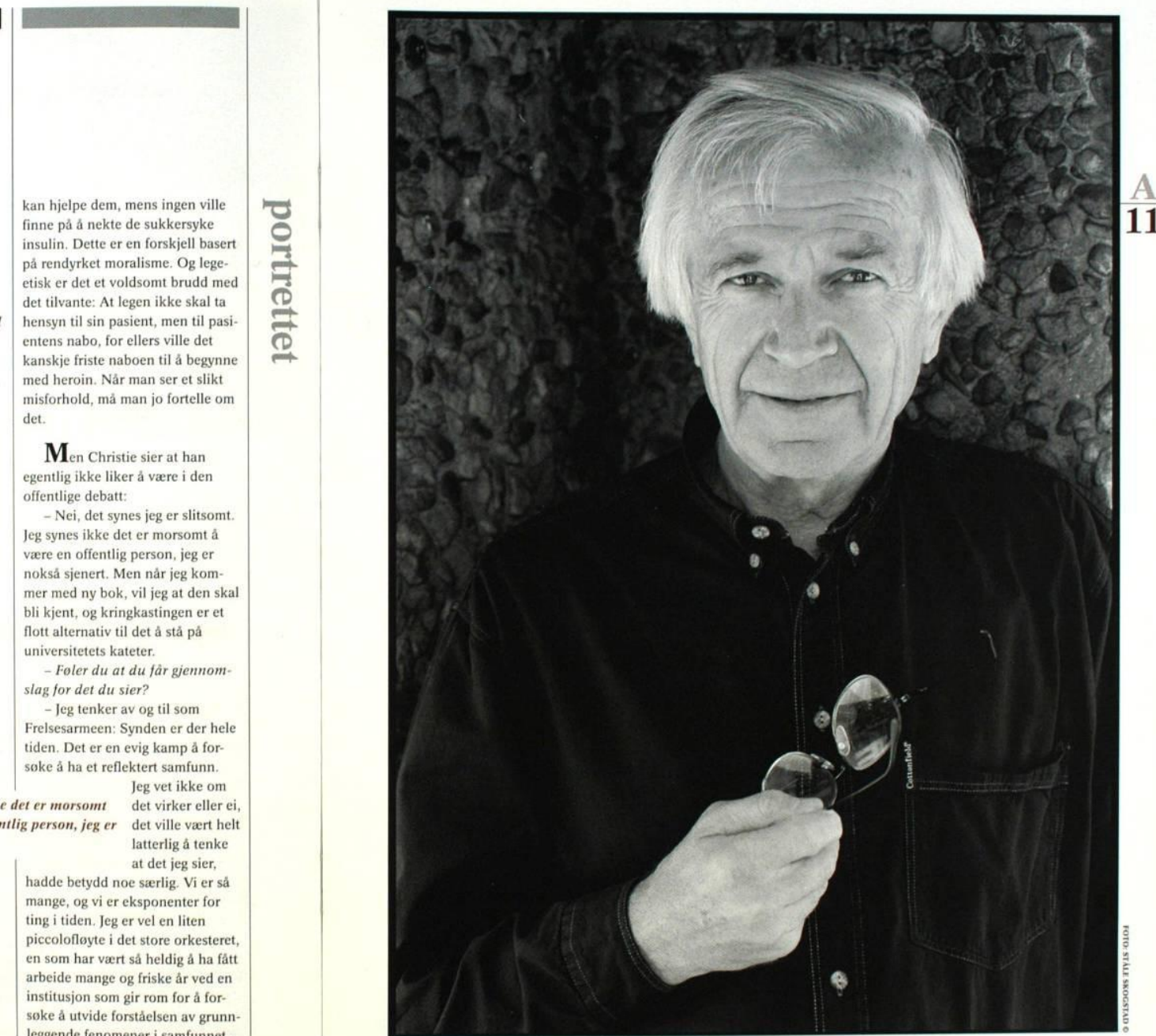